Stark, K.; Andersson, P.; Beresford, N.A.; Yankovich, T.L.; Wood, M.D.; Johansen, M.P.; Vives i Battle, J.; Twining, J.; Keum, D.-K.; Bollhofer, A.; Doering, C.; Ryan, B.; Grzechnik, M.; Vandenhove, H.. 2015. Predicting exposure of wildlife in radionuclide contaminated wetland ecosystems. Environmental Pollution, 196. 201-213.

https://doi.org/10.1016/j.envpol.2014.10.012

(C) 2014 Elsevier Ltd.

This manuscript version is made available under the CC-BY-NC-ND 4.0 license http://creativecommons.org/licenses/by-nc-nd/4.0/

(c)) EY-NC-ND

This version available http://nora.nerc.ac.uk/id/eprint/508717/

NERC has developed NORA to enable users to access research outputs wholly or partially funded by NERC. Copyright and other rights for material on this site are retained by the rights owners. Users should read the terms and conditions of use of this material at http://nora.nerc.ac.uk/policies.html\#access

NOTICE: this is the author's version of a work that was accepted for publication in Environmental Pollution. Changes resulting from the publishing process, such as peer review, editing, corrections, structural formatting, and other quality control mechanisms may not be reflected in this document. Changes may have been made to this work since it was submitted for publication. A definitive version was subsequently published in Environmental Pollution, 196. 201-213.

https://doi.org/10.1016/j.envpol.2014.10.012

www.elsevier.com/

Contact CEH NORA team at noraceh@,ceh.ac.uk

The NERC and CEH trademarks and logos ('the Trademarks') are registered trademarks of NERC in the UK and other countries, and may not be used without the prior written consent of the Trademark owner. 


\section{PREDICTING EXPOSURE OF WILDLIFE IN RADIONUCLIDE CONTAMINATED WETLAND ECOSYSTEMS}

K. Stark ${ }^{\mathrm{a}, *}$, P. Andersson ${ }^{\mathrm{b}}$, N.A. Beresford ${ }^{\mathrm{c}}$, T.L. Yankovich ${ }^{\mathrm{d}}$, M.D. Wood ${ }^{\mathrm{e}}$, M.P. Johansen ${ }^{\mathrm{f}}$,

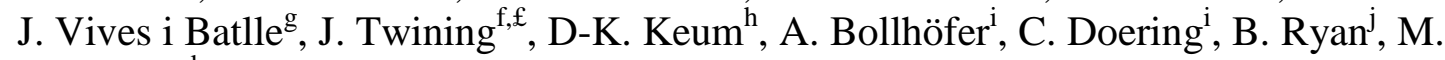
Grzechnik $^{\mathrm{k}}, \mathrm{H}$. Vandenhove $\mathrm{g}^{\mathrm{g}}$

${ }^{a}$ Department of Ecology, Environment, and Plant Sciences, Stockholm University, 10691 Stockholm, Sweden ${ }^{\mathrm{b}}$ Department of Radiation Protection, Swedish Radiation Safety Authority, 17116 Stockholm, Sweden ${ }^{\mathrm{c}}$ NERC Centre for Ecology \& Hydrology, CEH Lancaster, Lancaster Environment Centre, Library Av., Bailrigg, Lancaster, LA1 4AP, UK

${ }^{\mathrm{d}}$ International Atomic Energy Agency, Assessment and Management of Environmental Releases Unit, P.O. Box 100, 1400 Vienna, Austria

${ }^{\mathrm{e}}$ School of Environment and Life Sciences, University of Salford, Peel Building, Manchester M5 4WT, UK ${ }^{\mathrm{f}}$ Institute for Environmental Research, Australian Nuclear Science and Technology Organisation, Locked Bag 2001, Kirrawee DC NSW 2232, Australia

${ }^{g}$ Biosphere Impact Studies Unit, Belgian Nuclear Research Centre, SCK•CEN, Boeretang 200, BE-2400 MOL, Belgium

${ }^{\mathrm{h}}$ Nuclear Environment Safety Research Division, Korea Atomic Energy Research Institute, 150 Deokjindong, Yuseonggu, Daejeon 305-353, Republic of Korea

${ }^{\mathrm{i}}$ Environmental Research Institute of the Supervising Scientist, Department of the Environment, GPO Box 461, Darwin NT 0801, Australia

${ }^{j}$ Paulka Radiation and Environment, PO Box 39, Prospect, SA 5082, Australia

${ }^{\mathrm{k}}$ Radiation Health Services Branch, Australian Radiation Protection and Nuclear Safety Agency, 619 Lower Plenty Road, Yallambie VIC 3085, Australia

${ }^{£}$ Current address: Austral Radioecology, 8A Rickard Rd, Oyster Bay, 2225, Australia

*Corresponding author. Tel.: +468 164213; fax: +468158417

E-mail addresses: karolina.stark@su.se (K. Stark), pal.andersson@ssm.se (P. Andersson), nab@ceh.ac.uk (N.A. Beresford), t.yankovich@iaea.org (T.L. Yankovich), m.d.wood@salford.ac.uk (M. D. Wood), mathew.johansen@ansto.gov.au (M. Johansen), jvibatll@SCKCEN.BE (J. Vives i Batlle), john.twining@ausradeco.com.au (J. Twining), dkkeum@kaeri.re.kr (D-K. Keum), andreas.bollhoefer@environment.gov.au (A. Bollhöfer), che.doering@environment.gov.au (C. Doering), Bruce.Ryan@ paulka.com.au (B. Ryan), Marcus.Grzechnik@arpansa.gov.au (M. Grzechnik), hvandenh@ SCKCEN.BE (H.

Vandenhove) 
Highlights (for review)
Highlights:
1) Terrestrial parameters provided acceptable predictions for wetland species.
2) Choice of reference organism and occupancy factor resulted in largest differences.
3) Soil density and saturation should be considered when assessing doses in wetlands

Highlights (for review)
Highlights:
1) Terrestrial parameters provided acceptable predictions for wetland species.
2) Choice of reference organism and occupancy factor resulted in largest differences.
3) Soil density and saturation should be considered when assessing doses in wetlands

Highlights (for review)
Highlights:
1) Terrestrial parameters provided acceptable predictions for wetland species.
2) Choice of reference organism and occupancy factor resulted in largest differences.
3) Soil density and saturation should be considered when assessing doses in wetlands

Highlights (for review)
Highlights:
1) Terrestrial parameters provided acceptable predictions for wetland species.
2) Choice of reference organism and occupancy factor resulted in largest differences.
3) Soil density and saturation should be considered when assessing doses in wetlands

Highlights (for review)
Highlights:
1) Terrestrial parameters provided acceptable predictions for wetland species.
2) Choice of reference organism and occupancy factor resulted in largest differences.
3) Soil density and saturation should be considered when assessing doses in wetlands.

.

(3)

(1)

(1)

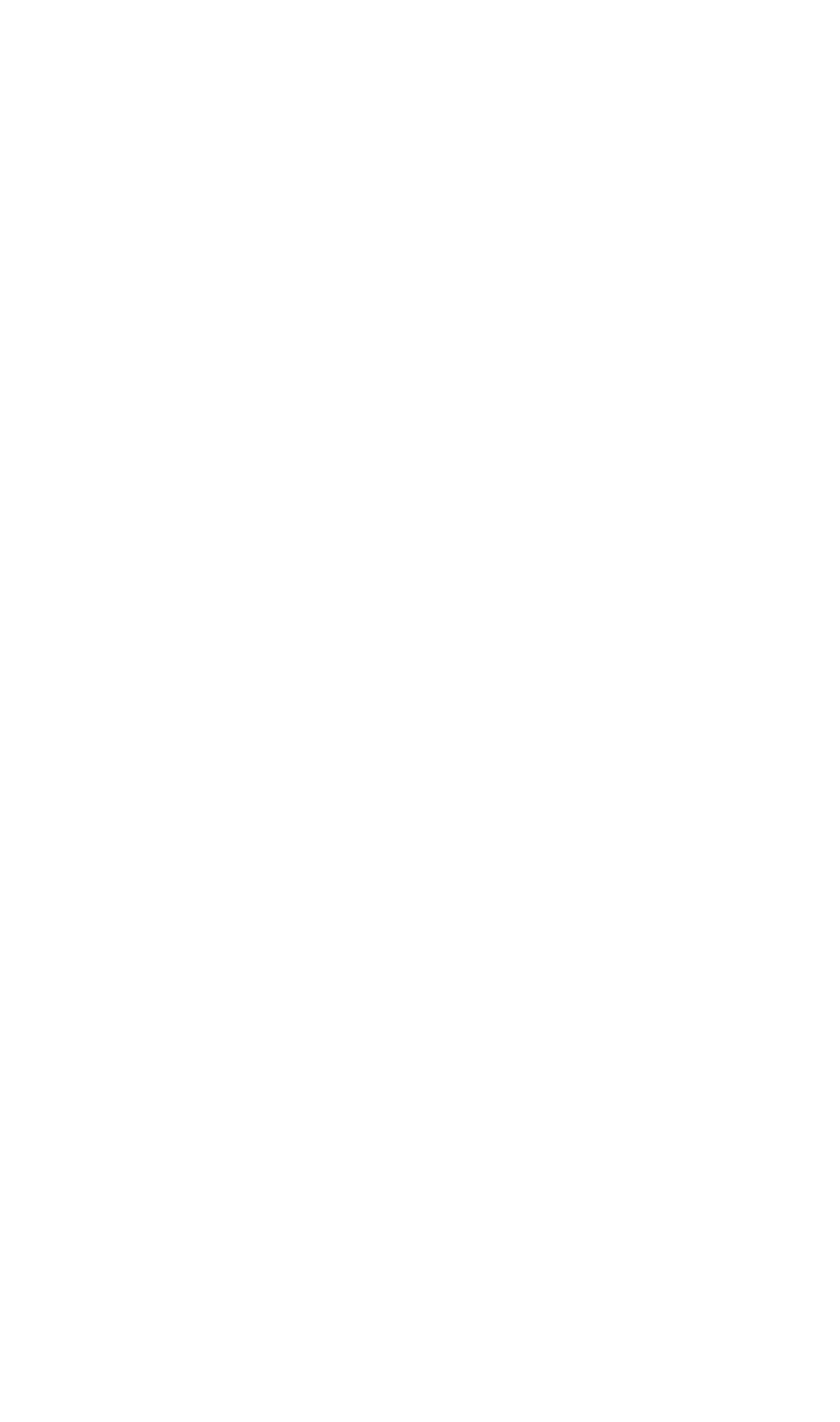




\begin{abstract}
Many wetlands support high biodiversity and are protected sites, but some are contaminated with radionuclides from routine or accidental releases from nuclear facilities. This radiation exposure needs to be assessed to demonstrate radiological protection of the environment. Existing biota dose models cover generic terrestrial, freshwater, and marine ecosystems, not wetlands specifically. This paper, which was produced under IAEA's Environmental Modelling for Radiation Safety (EMRAS) II programme, describes an evaluation of how models can be applied to radionuclide-contaminated wetlands. Participants used combinations of aquatic and terrestrial model parameters to assess exposure. Results show the importance of occupancy factor and food source (aquatic or terrestrial) included. The influence of soil saturation conditions on external dose rates is also apparent. In general, terrestrial parameters provided acceptable predictions for wetland organisms. However, occasionally predictions varied by three orders of magnitude between assessors. Possible further developments for biota dose models and research needs are identified.
\end{abstract}

Keywords: biota dose model, radiation dose, swamp, ${ }^{137}$ Cesium, ${ }^{14}$ Carbon

Capsule: Terrestrial parameters provide acceptable predictions for wetland organisms 


\section{Introduction}

2 With a renewed interest in nuclear power in many countries (Marcus, 2008; Joskow and

3 Parsons, 2012) and with the recognition by the International Commission on Radiological

4 Protection (ICRP) for an explicit consideration of radiological protection of the environment

5 (ICRP, 2007; 2009), robust methods for assessing radiation doses and effects to wildlife are

6 becoming increasingly important. This challenging task has been addressed by radioecologists

7 by the development of a number of biota dose estimation models (see Vives i Batlle et al., 2011; Beresford et al., 2009) that can be used in environmental risk assessments such as the ERICA Tool (Brown et al., 2008) and RESRAD-Biota (USDoE, 2004) which are freely available software. However, these models are in need of validation. Modelling for Radiation Safety (EMRAS) programme in 2005-2008 (IAEA, 2012) and EMRAS II in 2009-2012 (IAEA in-press) to facilitate international collaboration for improving environmental dose assessments. Within these programmes biota dose model intercomparisons were performed for terrestrial (Beresford et al., 2010; Johansen et al., 2012), and 16 freshwater lake ecosystems (Yankovich et al., 2010; IAEA, in-press). These studies showed that model results can vary by up to three orders of magnitude in dose predictions (Beresford et al., 2010; Johansen et al., 2012), with most variation attributed to modelled uptake of radionuclides by organisms. To help refine the models, further inter-comparison exercises were recommended (Beresford et al., 2009), especially for those exposure scenarios not specifically considered in available models and radionuclide-organism combinations not yet assessed.

In general, current biota dose models consider three generic ecosystem types: terrestrial, freshwater, and marine. Available models do not consider wetlands explicitly, although, RESRAD-Biota does include an option to assess riparian animals. However, such 
ecosystems require assessment, as numerous wetlands are protected under the RAMSAR convention (Mitsch and Gosselink, 2000), support high biodiversity, and data show that some are contaminated with radionuclides (see below).

There are a variety of wetland types, with a range of typical features. Wetlands include the structural groups: marshes, swamps, bogs, and fens (Tiner, 1999). Marshes are defined as regularly or constantly flooded wetlands with emergent, herbaceous vegetation adapted to saturated soil conditions and mineral soil substrates (Mitsch and Gosselink, 2000). Swamps are dominated by trees or shrubs and often have a high biodiversity and productivity. Wetlands dominated by reed grasses and forested fens can be included in the swamps category. Bogs are peat-accumulating wetlands that have no significant inflows or outflows and support acidophilic mosses. Fens are also peat-accumulating but receive some drainage inflow from surrounding mineral soils and usually support marsh-like vegetation.

This study focused on swamps in temperate/sub-tropical regions, which often are wetlands that can be nutrient sinks, filtering particles from temporarily inflowing water. Many radionuclides have an affinity to sediment particles and these types of wetlands may, therefore, accumulate and function as sinks for such radionuclides (e.g., Walling and Bradley, 1988; Burrough et al., 1999; Kaplan et al., 2014).

The objective of this study was to investigate how current models for wildlife radiation dose assessments can be applied to radionuclide contaminants (particularly ${ }^{137} \mathrm{Cs}$ and ${ }^{14} \mathrm{C}$ ) in wetlands. Here we report results of a model-to-model inter-comparison exercise considering three wetlands. We focused on differences between how exercise participants, representing 'informed users' and model developers (Wood et al., 2009), approached a wetland scenario, to evaluate differences in predictions between different model applications used to run the scenario. 


\section{Methods}

\subsection{Biota dose models and participants}

Six groups participated in this inter-comparison exercise (Table 1) using different models, namely K-Biota (Keum, 2012; Keum et al., 2011), RESRAD-Biota (USDoE, 2004) and ERICA Tool (Brown et al., 2008). Four groups used the ERICA Tool, of which two used included default transfer parameters (concentration ratios, CRs) (Beresford et al., 2008; Hosseini et al., 2008) and two used CRs from the IAEA technical report series (TRS) handbook on wildlife transfer (IAEA, 2014; Howard et al., 2013; Yankovich et al. 2013b). The handbook on wildlife transfer, referred to as the TRS in the subsequent text, was also used with RESRAD-Biota and K-Biota applications. It should be noted that the database underlying the TRS was initially based upon the ERICA Tool, with additional data being added where available (Copplestone et al., 2012).

\subsection{Description of the wetland areas}

Data from three wetlands were combined to provide a range of organisms, soil types, and radionuclides: Steel Creek Swamp (South Carolina, USA), Utnora Swamp (Sweden), and

Duke Swamp (Canada) (Table 2). Routine releases were the cause of contamination in Steel

Creek Swamp while accidental releases contaminated Utnora and Duke Swamp.

\subsubsection{Steel Creek Swamp}

Steel Creek, a $20 \mathrm{~km}$ long creek, drains a $290 \mathrm{~km}^{2}$ watershed (Figure 1) situated on the US Department of Energy Savannah River Site in South Carolina, USA (N3306'50’, W81 $\left.37^{\prime} 50^{\prime \prime}\right)$. The creek received cooling water from nuclear reactors between 1954 and 1974 (Paller et al., 2008). A floodplain borders the main channel and the creek is shallow (< $1 \mathrm{~m})$ and 3 - $5 \mathrm{~m}$ wide. Soil was sampled down to a depth of 1 meter along three transects perpendicular to the creek (Figure 1) and ${ }^{137} \mathrm{Cs}$ activity concentrations are available (Brisbin et al, 1974a). Most of the activity was in the top 10-cm of profiles. In addition, water, 
vegetation, amphibians, reptiles, and invertebrates activity concentrations were available (RAC, 2001; Brisbin et al., 1974b; Anderson et al., 1973; Dapson and Kaplan, 1975; Table 3).

\subsubsection{Utnora Swamp}

Utnora Swamp (Figure 2) is a $0.024 \mathrm{~km}^{2}$ riparian swamp next to Verkmyra Stream, which flows out of Hille Lake, in the central-eastern part of Sweden (N6046’20', E17¹6'30' '). The swamp received fallout following the Chernobyl accident in 1986. Verkmyra Stream floods the swamp every spring, resulting in deposition of radioactive material, mainly ${ }^{137} \mathrm{Cs}$ (Stark et al., 2006). Available samples from this area were soil/sediment profiles down to a depth of $50 \mathrm{~cm}$, water, vegetation, and amphibians (Stark et al., 2004; Stark unpublished data; Table 3). Most of the activity $(60-90 \%)$ in soil was found in the top 10-cm layer.

\subsubsection{Duke Swamp}

The Duke Swamp (Figure 3) is a $0.102 \mathrm{~km}^{2}$ wetland in the Atomic Energy of Canada Limited's Chalk River facility in Ontario, Canada (N4602'40', W77²4'40'”) that receives radionuclides, including ${ }^{14} \mathrm{C}$, through groundwater transport from a waste management area situated approximately 400 m east of the swamp (Kim et al., 2011; Yankovich et al., 2008a).

Past assessments indicated that the primary contributor to dose to biota is likely to be ${ }^{14} \mathrm{C}$ (Zach et al. 1998) from ${ }^{14} \mathrm{C}$ volatilised into the atmosphere rather than via direct transfer from groundwater (Yankovich et al. 2013a). A detailed survey of ${ }^{14} \mathrm{C}$ in soil to a depth of $5 \mathrm{~cm}$ and surface vegetation had been conducted. A subset of locations was selected for detailed biota sampling to obtain a range of activity concentrations across Duke Swamp. Samples included in this study were of soil, air, vegetation, invertebrates, amphibians, reptiles, and rodents (Yankovich et al., 2013a; Table 3). 


\subsection{Input data and exercise instructions}

100 Participants were given measured activity concentrations in soil, water, and air, as available

101 for the three wetland areas (Table 2). No other parameters were specified in the scenario

102 description, although basic information for sites and a list of species to consider were

103 provided (Table 3; IAEA in press). Soil concentrations were presented on a dry mass basis;

104 hence, fresh mass concentrations had to be estimated if required. Water concentrations (only

105 available for Steel Creek and Utnora Swamps), were given for filtered water. To provide soil

$106{ }^{14} \mathrm{C}$ concentration in Duke Swamp for those models requiring this input, available ${ }^{14} \mathrm{C}$ specific

107 activity concentrations in soil were calculated by assuming the mean soil organic matter

108 content determined for the site (95\%; Yankovich et al., 2014) and an assumed carbon content

109 of soil organic matter of 58\% (Brady, 1990).

110 Participants were asked to estimate whole organism radionuclide activity

111 concentrations, unweighted internal, external, and total absorbed dose rates to all species

112 listed in Table 3. Deterministically predicted best estimates of mean, minimum, and

113 maximum activity concentrations and average dose rates over a year were requested.

114 Evaluation included model-model comparisons of organism concentrations and dose rates,

115 model-measurement comparisons of organism concentrations and, for one species (frogs in

116 Utnora), model-measurement comparisons of external dose rate in soil.

1182.4 General approach taken by participants

119 For Steel Creek and Utnora Swamps, whole organism activity concentrations of ${ }^{137}$ Cs were

120 estimated by multiplying CRs with soil or water concentrations, given the assumptions being

121 made for the fraction of time spent feeding in aquatic or terrestrial environments. Internal and

122 external dose rates were estimated from assumed occupancy factors in air, on soil, in soil, on

123 water, in water, on sediment, and in sediment, together with dose conversion coefficients 
124 (DCCs). If default reference organisms were used, included DCCs were applied. Alternately,

125 DCCs were calculated by the models if new geometries approximating specific organisms

126 were considered to be required.

Two approaches were used to estimate biota concentrations of ${ }^{14} \mathrm{C}$ in Duke Swamp

128 (Table 1): I) the specific activity approach in which the specific activity ratio $\left(\mathrm{Bq}{ }^{14} \mathrm{C} / \mathrm{kg} \mathrm{C}\right)$

129 was assumed to be the same in the whole ecosystem. Each whole body activity concentration

$130(\mathrm{~Bq} / \mathrm{kg}$ fresh mass, $\mathrm{FM})$ was estimated from a given specific activity in air $(\mathrm{Bq} / \mathrm{kg} \mathrm{C})$

131 multiplied by whole body content of stable $\mathrm{C}$ in organisms ( $\mathrm{kg} \mathrm{C} / \mathrm{kg} \mathrm{FM})$. II) to use the

132 ERICA Tool default $\mathrm{CR}_{\mathrm{wo}}$ (whole organism concentration ratio; Howard et al., 2013) values

$133\left(\mathrm{~Bq} / \mathrm{kg}\right.$ per $\left.\mathrm{Bq} / \mathrm{m}^{3}\right)$ to convert air concentrations $\mathrm{Bq} / \mathrm{m}^{3}$ to organism activity concentrations (it 134 was suggested participants used the carbon concentration in air presented in IAEA (2010) to

135 estimate air ${ }^{14} \mathrm{C}$ concentrations). However, $\mathrm{CR}_{\mathrm{wo}} \mathrm{s}$ from the ERICA Tool were originally

136 derived through the specific activity approach assuming carbon content of biota from Robbins

137 (1993) and Crocker et al. (2002), as described by Brown et al. (2003).

139 3. Results and Discussion

$140 \quad 3.1$ Wetland assessment approaches taken by the assessors

141 Because none of the biota dose models used in this study were specifically developed for

142 wetlands, only their aquatic or/and terrestrial functions were available. As a result, species

143 from the wetlands were mainly assumed to feed in terrestrial systems by all assessors, and

144 thus, mainly terrestrial CRs were used in predictions (Table 4). However, a few organisms

145 were assumed to be aquatic or to occupy or feed from aquatic environments for various

146 fractions of time (Table 4 and 5). Assessors assumed an organism to be terrestrial or aquatic

147 according to supporting information they identified about the species. 
150 Differences in results between assessors for predicted biota activity concentrations of ${ }^{137} \mathrm{Cs}$ in

151 Steel Creek and Utnora Swamp (Figure 4 and 5) were mainly due to differences in

152 assumptions of transfer from terrestrial and aquatic sources and the choice of reference

153 organism to represent wetland species. In Duke Swamp, differences in predicted activity

154 concentrations of ${ }^{14} \mathrm{C}$ (Figure 6) mainly depended on differences in assumed carbon content of 155 organisms.

\subsubsection{Choice of ecosystem and $C R_{w o}$-value}

In Steel Creek Swamp, the ERICA (CEH) application only used an aquatic $\mathrm{CR}_{\mathrm{wo}}$ for duck and gave a lower estimated biota activity concentration, even though it was assumed to spend part of the time on land. The assessor justified this on the basis of the importance of the freshwater environment as food source for typical duck species. This resulted in a difference in predicted activity concentrations between assessors by a factor of seven for duck in Steel Creek Swamp (Figure 4). Differences between predicted activity concentrations for shrubs, frogs, and snakes were mainly caused by differences in $\mathrm{CR}_{\mathrm{wo}}$ between the two databases in the ERICA Tool and TRS (IAEA, 2014), which was less than a factor of two for most organisms, although a sevenfold difference were predicted for terrestrial snake. For terrestrial reptiles, the TRS CR $\mathrm{wo}_{\mathrm{w}}$

167 value for Cs is a factor of seven lower than the ERICA CR $\mathrm{wo}_{\mathrm{wo}}$. Barnett et al. (2009) had previously observed errors in the derivation of the ERICA CR ${ }_{w o}$ for reptiles (corrected in the TRS dataset).

In Utnora Swamp the largest variation in predicted activity concentrations of

$171{ }^{137} \mathrm{Cs}$ was for forbs and sedges, mainly because the ERICA(CEH) application used freshwater

172 vascular plant as reference organism (justified by the assessor on the basis of species listed for 173 the site), and thus, water as surrounding medium. Consequently, results varied up to three 
174 orders of magnitude between assessors (Figure 5). For Moor frog, the two applications that

175 included aquatic transfer to frog $(\mathrm{K}$-Biota and ERICA $(\mathrm{SCK} \cdot \mathrm{CEN})$ resulted in the lowest

176 predictions.

177

178

179

180

181

182

183

184

185

186

187

188

189

190

191

192

193

194

195

196

197

198

\subsubsection{Choice of reference organism}

Another source of difference between predicted activity concentrations was the choice of reference organism to represent the exercise species, for example, whether to choose detritivorous or flying insect to represent beetles (in the ERICA Tool). In Steel Creek Swamp, these differences were generally less than a factor of three. However, the decision to allocate woody plants as trees or shrubs was of more consequence, as difference in $\mathrm{CR}_{\mathrm{wo}}$ between trees and shrubs was more than a factor of 15 for both the ERICA Tool and TRS datasets. This resulted in a relatively large difference in predictions for willow in Steel Creek, which was represented as a tree by most assessors but as a shrub in the RESRAD-Biota application. For Utnora Swamp, different choices of reference organism (herb/grass/shrub) to represent fern also resulted in a difference by a factor of six for fern activity concentrations between assessors.

\subsection{3 ${ }^{14}$ C transfer}

In general, differences between assessors in predicted ${ }^{14} \mathrm{C}$ activity concentrations in biota were small for Duke Swamp, with estimated mean values varying by a factor of four or less (Figure 6). However, differences of one order of magnitude were predicted for insects largely due to varying ${ }^{14} \mathrm{C}$ approach used (Table 1) and assumed carbon content of biota. One explanation of the relatively large difference in assumed carbon content, besides choosing different reference organisms to represent species, is that it should be expressed on a fresh mass basis, and thus, assumption of water content influenced results. 


\subsection{Measured biota activity concentrations}

201 When comparing predicted activity concentrations to measured values in biota, predictions

202 between 3 times above or 3 times below the measured value may be considered good. In Steel 203 Creek Swamp, 44\% of the predictions were within the described range (Figure 4). The assessors under-predicted activity concentrations in arthropods by an order of magnitude depending upon the chosen reference organism. For example, the difference in $\mathrm{CR}_{\mathrm{wo}}$ between mean arthropod and mean herbivorous arthropod in the TRS is a factor of 11. ERICA (CEH)

207 parameterised both aphids and grasshoppers as herbivorous (lower $\mathrm{CR}_{\mathrm{wo}}$ ), the RESRAD-Biota application represented both groups by the overall mean arthropod, while the ERICA $(\mathrm{SCK} \cdot \mathrm{CEN})$ and $\mathrm{K}-\mathrm{BIOTA}$ applications parameterised aphids using the herbivorous $\mathrm{CR}_{\mathrm{wo}}$ and grasshoppers using the overall mean arthropod value. The original data for arthropods at Steel Creek Swamp were reported on dry mass basis, so there were some uncertainties in the 212 conversion to fresh mass.

214 Swamp, predictions were in the same order of magnitude to measured values and $96 \%$ were within the described range (between 3:1 - 1:3; Figure 4). When estimating activity concentrations in duck, applications using partly a soil $\mathrm{CR}_{\mathrm{wo}}$ and partly an aquatic $\mathrm{CR}_{\mathrm{wo}}$

217 resulted in estimates deviating by only $20 \%$ from measured values. For vegetation, all

218 modellers used $\mathrm{CR}_{\mathrm{wo}} \mathrm{s}$ for tree to represent alder, and all but the RESRAD-Biota application 219 used the tree $\mathrm{CR}_{\mathrm{wo}}$ for willow. This resulted in lower concentrations in alder and willow, compared to shrub species (mainly wax myrtle), which were modelled using a shrub $\mathrm{CR}_{\mathrm{wo}}$.

221 Field data from Steel Creek Swamp, however, showed no differences between these three 222 species (leaf samples), and the alder (Alnus serrulata) and willow (Salix nigra) species 223 dominating the site were shrubs rather than trees. 
magnitude higher than measured values and none were within the described range $(3: 1-1: 3$;

Figure 5). Thus, less ${ }^{137} \mathrm{Cs}$ is taken up by organisms (spruce, fern, alder tree, forbs/sedges, moor frog) than predicted using biota dose models. The only exception was the ERICA

$228(\mathrm{CEH})$ application that used a freshwater plant $\mathrm{CR}_{\mathrm{wo}}$ as representative of forbs and sedges, which under-predicted the activity concentration by a factor of four. Possibly, this difference between predictions and measurements could be explained by the fact that ${ }^{137} \mathrm{Cs}$ has an affinity to sediment particles as exemplified by the partition coefficient, $\mathrm{K}_{\mathrm{d}}$, of $2635 \mathrm{~L} \mathrm{~kg}^{-1}$

232 (defined below in section 3.5). It is likely that ${ }^{137} \mathrm{Cs}$ in Utnora Swamp is attached to particles 233 from the upstream lake and transported by the outlet stream that floods the swamp. This has 234 resulted in ${ }^{137} \mathrm{Cs}$ deposits located mainly in the top 10-cm of soil layers (Stark et al., 2006), possibly making it less bioavailable for deeper plant roots. described range (3:1 - 1:3; Figure 6). Average measured values differed by less than a factor 238 of seven from predictions, except for insects. As was seen for Steel Creek for ${ }^{137}$ Cs, predicted activity concentration of ${ }^{14} \mathrm{C}$ in insects were approximately one order of magnitude higher than measured data. For small plants, predictions were close to measured values. However,

241 for trees, all predictions were consistently higher (up to a factor of 4) than measured data.

242 Yankovich et al. (2013a) reports that previous studies observed an exponential decrease in ${ }^{14} \mathrm{C}$ 243 specific activity concentrations in vegetation with height above ground at this site, possibly 244 the consequence of activity concentrations in air reducing with height as ${ }^{14} \mathrm{CO}_{2}$ and ${ }^{14} \mathrm{CH}_{3}$ 245 disperse with distance from the source (i.e. the ground surface). Air samplers providing input 246 air concentrations were located at ground surface, so an over-prediction in trees is not 247 surprising. 
250 Internal dose rates are directly proportional to biota activity concentrations and to the dose

251 conversion coefficient, with the latter in turn depending on organism composition and

252 dimensions and the energies of the radioactive decays considered. As a result, the spread in

253 predictions in Steel Creek and Utnora Swamps discussed above was also manifested in

254 corresponding internal dose rates (Figure 7 and 8).

Estimated internal dose from ${ }^{14} \mathrm{C}$ to organisms in Duke Swamp (Figure 9) show

256 the same pattern as activity concentrations with the largest variation for insects. K-Biota

257 assumed 50\% occupancy, and 50\% feeding, in aquatic environment for frog, which resulted in

258 higher predictions than for other model applications.

\subsection{External dose rates}

\subsubsection{Assumption of occupancy factor}

262 Assumptions of occupancy factor for wetland organisms greatly influenced predicted external 263 dose rates. For Steel Creek Swamp, the most obvious difference between assessors was the 264 dominance of external dose rate in the aquatic environment for tree frog and aquatic snake for the ERICA (SCK•CEN) application (Figure 7). This difference resulted from the assumption that frogs and snakes spend time in or on bottom sediment. The sediment activity concentration was estimated by means of the default sediment-to-water partition coefficient 268 ( $\mathrm{K}_{\mathrm{d}}$-value) given in the ERICA-Tool (Brown et al., 2008), which is defined as:

$$
K d\left(L \cdot \mathrm{kg}^{-1}\right)=\frac{\text { Activity concentration in sediment }\left(B q \cdot \mathrm{kg}^{-1} \mathrm{dry} \text { mass }\right)}{\text { Activity concentration in water }\left(B q \cdot \mathrm{L}^{-1}\right)}
$$

269 The estimated sediment activity concentration was approximately 30 times higher than 270 measured values. This result highlights the importance of the occupancy factor assumptions, 271 and that default $\mathrm{K}_{\mathrm{d}}$ values may not replicate field conditions due to a range of site-specific 272 factors. 
274 Swamp, the RESRAD-Biota application predicted consistently higher estimates (by a factor

275 two to three) than other applications. A key difference between RESRAD-Biota and the

276 ERICA Tool is that the former allows plants to be located above and below the soil surface

277 (the assessor assumed 50\% occupancy in soil), whereas terrestrial plant geometries in the

278 ERICA Tool are assumed to be on the soil surface. This likely explains most of the difference

279 in external dose rates between the two models.

The ERICA (CEH) application that chose an aquatic vascular plant for

281 forbs/sedges, predicted external dose rates within the range of predictions by other

282 applications, despite different assumptions on location (Figure 8). Results from the ERICA

283 Tool were inconsistent with those generated using other approaches, in that it models aquatic

284 vascular plant as being 50\% in and 50\% above sediment, whereas terrestrial plants are

285 modeled on the soil surface.

Carbon-14 range in tissues is very short and the dose to biota is dominated by

internal dose. This means that any assumptions of occupancy within a given environment have little impact on the results.

\subsubsection{Soil saturation assumptions}

291 Another influential parameter for external dose rates in terrestrial parts of the wetland was

292 assumptions used for soil moisture. For Steel Creek Swamp, the ERICA (ANSTO)

293 application, and for Utnora Swamp the ERICA (eriss/ARPANSA), (ANSTO), and (CEH)

294 applications, estimated external dose rates $10 \%$ of those predicted using other applications.

295 These results are explained by use of the option in the ERICA Tool to define soil/sediment

296 dry matter percentage. External dose rates are calculated by the ERICA Tool in a manner

297 intended to be representative of exposure conditions in the field. However, soil concentration 
data are usually given on a dry mass basis which, for wetland soils, can be very different than field conditions. By specifying a dry matter percentage, the ERICA Tool back-calculates the

300 fresh mass soil concentration from dry mass concentrations that are required input. The

301 default, conservative value of dry matter percentage in the ERICA Tool is $100 \%$, but it might

302 be appropriate to enter lower values if in situ dry matter percentage is known at the site. In 303 this scenario, a 10\% soil dry matter percentage was given for Duke Swamp and was used in 304 ERICA (ANSTO) for all wetland soils. The resulting external dose rates were a factor of ten 305 lower than they would have been if the option to define dry matter percentage was not used. 306 This is because in the ERICA Tool, external dose rates decreased corresponding to entered 307 percentage. The importance of using the dry matter percentage functionality in ERICA Tool is particularly well illustrated in our wetland scenario, where dry matter percentage is likely to be low. It highlights that input of site-specific soil dry matter percentage is either not available 311 in some codes, or is typically not used by most practitioners. While the adjustment is easily 312 made using the ERICA Tool, it could also be achieved using other models by making separate model runs for internal and external dose rates, using different soil activity concentrations.

314 Code developers could improve dose estimation for wetlands by adding required functionality 315 and clarifying instructions to users. Assessors should be aware of the DCCs being defined on 316 a fresh soil mass basis and justify whether soil activity concentrations should be adjusted to 317 reflect this, or if the input should be on a dry mass basis.

\subsubsection{Predicted and measured external dose rates to Moor frog}

320 For Moor frog in Utnora Swamp, predicted external dose rates varied by a factor of 10 . As for 321 other organisms, the largest difference in predictions was due to assumptions of dry matter 322 percentage for soil. Also, some differences were due to choices of occupancy. It is evident 
that all models produce similar predictions for an occupancy of $100 \%$ in soil (Figure 10; but only if all modellers used the same dry matter percentage for soil). Surprisingly, in contrast to tree frog in Steel Creek Swamp, external doses from sediments is not dominating in the ERICA $(\mathrm{SCK} \cdot \mathrm{CEN})$ application, despite an assumed occupancy of $25 \%$ in sediment. The explanation for this is that sediment concentration was derived from water concentration through a $\mathrm{K}_{\mathrm{d}}$ value for marine ecosystems because the swamp was interpreted as being influenced by the Baltic Sea. However, in Utnora Swamp this is unlikely because a thick reed belt separates the swamp from the sea and the swamp is flooded by a freshwater stream coming from an upstream lake. An estimate based on a freshwater $\mathrm{K}_{\mathrm{d}}$ value would have resulted in a two orders of magnitude higher sediment concentration. Estimates of external dose rate to Moor frog from a study using phantoms and thermoluminescent dosimeters (TLDs) (Stark and Pettersson, 2008) were available for comparison with predictions. Dose rate estimates from ERICA (eriss/ARPANSA) and ERICA (ANSTO), assuming 10\% soil dry matter percentage, were similar to measured values (Figure 10). Soil dry matter percentage varied between 20\% and 50\% (Stark and Pettersson, 2008), although this information was not provided to participants. A third assessor, ERICA (CEH), estimated dose rates to Moor frog assuming $10 \%$ dry matter percentage in soil (for minimum dose) and up to $100 \%$ dry matter percentage in soil (for maximum dose), resulting in a large range. The assessors using the RESRAD-Biota and K-BIOTA models both assumed a 100\% dry matter percentage in soil and predicted ranges that were approximately an order of magnitude higher than measured values.

\subsection{General aspects}

The models included in this exercise all consider terrestrial and freshwater ecosystems but only RESRAD-Biota, through the possibility to model riparian animals (USDoE, 2004), 
includes the capacity to directly assess vertebrate wetland organisms. This functionality of RESRAD-Biota was not used by any modeller in this exercise.

As the allometric relationships presented in RESRAD-Biota are for mammals and birds, they are not applicable to the majority of vertebrates (reptiles and amphibians) considered in this study (Beresford and Vives i Batlle, 2013). For the purpose of comparison, we used the allometric relationships to make predictions for duck at Steel Creek Swamp under different assumptions of diet. We defined an organism approximating to a mallard duck (Anas platyrynchos) assuming: a default geometry of 4 (which is defined as a $1 \mathrm{~kg}$ organism); a soil geometry factor of 0.25 (representing $50 \%$ occupancy on soil for a $2 \pi$ exposure geometry); a water geometry factor of 0.25 ; an area factor of 1 (which assumes $100 \%$ of time is spent in the assessment area); and a dry matter food intake of $72 \mathrm{~g} \mathrm{~d}^{-1}$ for generic birds of $1 \mathrm{~kg}$ live-mass (Nagy, 2001).

The geometric mean $\mathrm{CR}_{\mathrm{wo}-\text { media }}$ from IAEA (2014) was used to provide best estimate (Wood et al., 2013). Assuming a 100\% aquatic plant diet, RESRAD-Biota predicted an activity concentration of $110 \mathrm{~Bq} \mathrm{~kg}^{-1}(\mathrm{FM})$ and total dose rate of $0.27 \mu \mathrm{Gy} \mathrm{h}^{-1}$. If a diet of terrestrial plants was assumed, an activity concentration of $4070 \mathrm{~Bq} \mathrm{~kg}^{-1}(\mathrm{FM})$ and dose rate of $0.97 \mu \mathrm{Gy} \mathrm{h}^{-1}$ were estimated. Accepting that mallards are omnivorous, a diet comprising $20 \%$ aquatic benthic invertebrates, $30 \%$ aquatic plants and $50 \%$ terrestrial plants resulted in activity concentration of $2430 \mathrm{~Bq} \mathrm{~kg}^{-1}$, with a dose rate of $0.68 \mu \mathrm{Gy} \mathrm{h}^{-1}$. Again these results highlight the importance of assumed food source for wetland organisms. Assuming a diet of $100 \%$ aquatic plants resulted in an under-estimation of uptake by one order of magnitude, while a mixture of terrestrial and aquatic food produced predictions close to measurements 370 (Figure 4).

To assess the risk for each contaminated wetland is beyond the scope of this 372 study but for the purpose of comparison to a screening value of $10 \mu \mathrm{Gy} \mathrm{h}^{-1}$, below which 
374 Swamp exceeded $10 \mu \mathrm{Gy} \mathrm{h}{ }^{-1}$. For Utnora Swamp three predicted doses were above $10 \mu \mathrm{Gy} \mathrm{h}$

375 , while measurements showed that actual levels were up to two orders of magnitude lower.

376 For Duke Swamp all predicted doses were well below the screening value.

\section{Conclusions}

This study highlights effects of the many aspects to consider when assessing wetlands, in particular the influence of water. To make a site-specific assessment, knowledge of seasonal water level is required, as well as habitat use and occupancy patterns of organisms during the year. Current biota dose models are not explicitly formulated for wetland conditions. Rather, doses to biota in wetlands must be estimated using terrestrial and aquatic parameters. In this respect, our scenario was well-suited to bring to light effects of different methodological assumptions. In general, using terrestrial parameters can provide acceptable and conservative predictions for wetland organisms. However, for some organisms, such as duck, a combination of terrestrial and aquatic food sources may give better predictions. Predicted biota activity concentrations and external and internal dose rates were in general within the same order of magnitude but occasionally varied up to three orders of magnitude between

390 participants. In contrast to previous inter-comparison studies where results varied most with

391 transfer, different choices of reference organisms and occupancy factors for wetland species

392 resulted in largest differences in predictions (in part, because all assessors used one of two concentration ratio (CR) datasets). In addition, assumptions of food sources (terrestrial or

394 aquatic) influenced choices of CR value. The dry matter percentage in soil influenced external 395 doses by an order of magnitude and we recommend that soil saturation is explicitly taken into 396 account. Also, predicted uptake of ${ }^{137} \mathrm{Cs}$ and ${ }^{14} \mathrm{C}$ in arthropods differed by an order of 
398 improve predictions.

\section{Acknowledgements}

401 This study was produced under IAEA's EMRAS II programme.

\section{References}

404

405

406
Anderson, G.E., Gentry, J.B., Smith, M.H., 1973. Relationships between levels of radiocesium in dominant plants and arthropods in a contaminated streambed community. Oikos 24(2), 165-170.

Barnett, C.L., Gaschak, S., Beresford, N.A., Howard, B.J., Maksimenko, A., 2009. Radionuclide activity concentrations in two species of reptiles from the Chernobyl exclusion zone. Radioprotection 44 (5), 537-542.

Beresford, N.A., Barnett, C.L., Howard, B.J., Scott, W.A., Brown, J.E., Copplestone, D., 2008. Derivation of transfer parameters for use within the ERICA Tool and the default concentration ratios for terrestrial biota. J. Environ. Radioact. 99, 1393-1407.

Beresford, N.A., Barnett, C.L., Beaugelin-Seiller, K., Brown, J.E., Cheng, J-J., Copplestone, D., Gaschak, S., Hingston, J.L., Horyna, J., Hosseini, A., Howard, B.J., Kamboj, S., Kryshev, A., Nedveckaite, T., Olyslaegers, G., Sazykina, T., Smith, J.T., Telleria, D., Vives i Batlle, J., Yankovich, T.L., Heling, R., Wood, M.D., Yu, C., 2009. Findings and recommendations from an international comparison of models and approaches for the estimation of radiological exposure to non-human biota. Radioprotection 44, 565-570.

http://dx.doi.org/10.1051/radiopro/20095104

Beresford, N.A., Barnett, C.L., Brown, J.E., Cheng, J.J., Copplestone, D., Gashchak, S., et al., 2010. Predicting the radiation exposure of terrestrial wildlife in the Chernobyl exclusion zone: an international comparison of approaches. J. Radiol. Prot. 30, 341-373.

Beresford, N.A., Vives i Batlle, J., 2013. Estimating the biological half-life for radionuclides in homeothermic vertebrates: a simplified allometric approach. Radiat. Environ. Biophys. 52(4), 505-511.

Brady, N.C., 1990. The nature and properties of soils. 10th ed. Macmillan Publishing Company, New York. ISBN 0-02-946159-6.

Brisbin, I.L., Beyers, R.J., Dapson, R.W., Geiger, R.A., Bentry, J.B., Gibbons, J.W., Smith, M.H., Woods, S.K., 1974a. Patterns of radiocesium in the sediments of a stream channel contaminated by production reactor effluents. Health Physics 27, 19-27. 
Brisbin, I.L., Staton, M.A., Pinder, J.E., Geiger, R.A., 1974b. Radiocesium concentrations of snakes from contaminated and non-contaminated habitats of the AEC Savannah River plant. Copeia 2, 501-506.

Brown, J., Strand, P., Hosseini, A., Børretzen, P., 2003. Handbook for assessment of the exposure of biota to ionising radiation from radionuclides in the environment. Fasset Deliverable 5, appendix 2, Framework for assessment of environmental impact, EC $5^{\text {th }}$ framework programme.

Brown, J.E., Alfonso, B., Avila, R., Beresford, N.A., Copplestone, D., Pröhl, G., Ulanovsky, A., 2008. The ERICA Tool. J. Environ. Radioact. 99, 1371-1383.

Burrough, P.A., Van Der Perk, M., Howard, B.J., Prister, B.S., Sansone, U., Voitsekhovitch, O.V., 1999. Environmental mobility of radiocaesium in the Pripyat catchment, Ukraine/Belarus. Water, Air, and Soil Pollution 110, 35-55.

Copplestone, D., Beresford, N.A., Brown, J., Yankovich, T., 2013. An international database of radionuclide concentration ratios for wildlife: development and uses. J. Environ. Radioact. 126, 288-298.

Crocker, D., Hart, A., Gurney, J., McCoy, C., 2002. Methods for estimating daily food intake of wild birds and animals, PROJECT PN0908, Central Science Laboratory, Department for Environment, Food and Rural Affairs.

Dapson, R.W., Kaplan, L., 1975. Biological half-life and distribution of radiocesium in a contaminated population of green tree frogs Hyla cinerea. Oikos 26(1), 39-42.

Hosseini, A., Thørring, H., Brown, J.E., Saxén, R., Ilus, E., 2008. Transfer of radionuclides in aquatic ecosystems - Default concentration ratios for aquatic biota in the ERICA Tool. J. Environ. Radioact. 99, 1408-1429.

Howard. B., Beresford, N., Andersson, P., Brown, J., Copplestone, D., Peaugelin-Seiller, K., Garnier-Laplace, J., Howe, P., Oughton D., Whitehouse. P., 2010. Protection of the environment from ionising radiation in a regulatory context - an overview of the PROTECT coordinated action project. J. Radiol.Prot. 30, 195-214.

Howard, B.J., Beresford, N.A., Copplestone, D., Telleria, D., Proehl, G., Fesenko, S. et al., 2013. The IAEA handbook on radionuclide transfer to wildlife. J. Environ. Radioact. 121, 5574.

IAEA, 2010. Handbook of parameter values for the prediction of radionuclide transfer in terrestrial and freshwater environment. Technical Reports Series No. 472. IAEA, Vienna.

IAEA, 2012. Modelling Radiation Exposure and Radionuclide Transfer for Non-human Species Report of the Biota Working Group of EMRAS Theme 3. Environmental Modelling for RAdiation Safety (EMRAS) Programme. International Atomic Energy Agency, Vienna; 2012.

IAEA, in press. Modelling the exposure of wildlife to radiation: evaluation of current approaches and identification of future requirements. Report of Working Group 4 of the EMRAS II Reference Approaches for Biota Dose Assessment. Environmental Modelling for 
RAdiation Safety (EMRAS II) Programme. International Atomic Energy Agency, Vienna; 2014.

IAEA, 2014. Handbook of parameter values for the prediction of radionuclide transfer to wildlife. International Atomic Energy Agency, Vienna. Technical report series. ISSN 00741914; no. 479.

International Commission on Radiological Protection (ICRP), 2007. The 2007

Recommendations of the International Commission on Radiological Protection. ICRP Publication 103. Ann. ICRP 37, (2-4).

International Commission on Radiological Protection (ICRP), 2009. Environmental protection; transfer parameters for reference animals and plants. ICRP Publication 114. Ann. ICRP 39, 6.

Johansen, M.P., Barnett, C.L., Beresford, N.A., Brown, J.E., Cerne, M., Howard, B.J. et al., 2012. Assessing doses to terrestrial wildlife at a radioactive waste disposal site: Intercomparison of modeling approaches. Sci. Tot. Environ. 427-428, 238-246.

Joskow, P.L., Parsons, J.E., 2012. The future of nuclear power after Fukushima. MIT CEEPR WP, 2012-001. http://hdl.handle.net/1721.1/70857

Kaplan, D.I., Zhang, S., Roberts, K.A., Schwehr, K., Xu, C., Creeley, D., Ho, Y-F., Li, H-P., Yeager, C.M., Santschi, P.H., 2014. Radioiodine concentrated in a wetland. J. Environ. Radioact. 131, 57-61.

Keum, D.K., 2012. K-BIOTA V2.0 user manual. KAERI-UM-18/2012 (Korean), Korea Atomic Energy Research Institute.

Keum, D.K., Jun, I., Lim, K.M., Choi, Y.H., 2011. Approach to non-human species radiation dose assessment in the Republic of Korea. Radiat. Prot. Dosimetry 146 (1-3), 299-302.

Kim, S.B., Chouhan, S.L., Davis, P.A., 2011. Observed and modelled tritium in the wetland ecosystem in Duke Swamp near a nuclear waste management area. Fusion Science and Technology 60(3), 960-963.

Marcus, G.H., 2008. Innovative nuclear energy systems and the future of nuclear power. Prog. Nucl. Energy 50, 92-96.

Mitsch, W.J., Gosselink, J.G., 2000. Wetlands. John Wiley \& Sons, New York, US.

Nagy, K.A., 2001. Food requirements of wild animals: predictive equations for free-living mammals, reptiles and birds. Nutr. Abs. Rev. 71, 21-31.

Paller, M.H., Jannik, G.T., Fledderman, P.D., 2008. Changes in ${ }^{137}$ Cs concentrations in soil and vegetation on the floodplain of the Savannah River over a 30 year period. J. Environ. Radioact. 99, 1302-1310.

Risk Assessment Corporation (RAC)., 2001. Savannah River Site Environmental dose reconstruction project, phase II: Source term calculation and ingestion pathway data retrieval, evaluation of materials released from the Savannah River Site. RAC Report No. 1-CDC-SRS- 
1999-Final. Risk Assessment Corporation.

http://www.cdc.gov/nceh/radiation/Savannah/Cover.pdf

Robbins, C.T., 1993. Wildlife feeding and nutrition. Academic Press, London.

Stark, K., Pettersson, H.B.L., 2008. External radiation doses from ${ }^{137}$ Cs to frog phantoms in a wetland area: in situ measurements and dose model calculations. Radiat. Environ. Biophys. 47, 481-489.

Stark, K., Avila, R., Wallberg, P., 2004. Estimation of radiation doses from ${ }^{137}$ Cs to frogs in a wetland ecosystem. J. Environ. Radioact. 75, 1-14.

Stark, K., Wallberg, P., Nylén, T., 2006. Post-depositional redistribution and gradual accumulation of ${ }^{137} \mathrm{Cs}$ in a riparian wetland ecosystem in Sweden. J. Environ. Radioact. 87, 175-187.

Stark, K. Department of Ecology, Environment, and Plant Sciences, Stockholm University, Sweden (unpublished data)

Tiner, R.W., 1999. Wetland indicators: a guide to wetland identification, delineation, classification and mapping. Boca Raton, Fla: Lewis Publishers. ISBN: 0-87371-892-5.

United States Department of Energy (USDoE), 2004. RESRAD-BIOTA: A tool for implementing a graded approach to biota dose evaluation. User's guide, version 1. DOE Report No. DOE/EH-0676; ISCORS Technical Report 2004-02, United States Department of Energy.

Vives i Batlle, J., Beaugelin-Seiller, K., Beresford, N.A., Copplestone, D., Horyna, J., Hosseini, A., Johansen, M., Kamboj, S., Keum, D-K., Kurosawa, N., Newsome, L., Olyslaegers, G., Vandenhove, H., Ryufuku, S., Vives Lynch, S., Wood, M.D., Yu, C., 2011. The estimation of absorbed dose rates for non-human biota: an extended intercomparison. Radiat. Environ. Biophys. 50(2), 231-251.

Walling, D.E., Bradley, S.B., 1988. Transport and redistribution of Chernobyl fallout radionuclides by fluvial processes: some preliminary evidence. Environ. Geochemistry and Health 10, 35-39.

Wood, M.D., Beresford, N.A., Barnett, C.L., Copplestone, D., Leah, R.T., 2009. Assessing radiation impact at a protected coastal sand dune site: an intercomparison of models for estimating the radiological exposure of non-human biota. J. Environ. Radioact. 100, 1034-52.

Wood, M.D., Beresford, N.A., Howard, B.J., Copplestone, D., 2013. Evaluating summarised radionuclide concentration ratio datasets for wildlife. J. Environ. Radioact. 126, 314-325.

Yankovich, T.L., Sharp, K.J., Benz, M.L., Carr, J., Killey, R.W.D., 2008a. Carbon-14 specific activity model validation for biota in wetland environments. Proceedings of the American Nuclear Society Topical Meeting on Decommissioning, Decontamination, and Reutilization, Chattanooga, Tennessee, 16-19 Sep 2007. Curran Associates, Inc., Red Hook, NY. Pp 91-94.

Yankovich, T.L., Kupferschmidt, D.A., Sharp, K.J., Benz, M.L., Kim, S.B., Shultz, C., Audette-Stuart, M., Carr, J., 2008b. Application of plants as biomarkers to assess wetland 
553 Yankovich, T.L., Vives i Batlle, J., Vives-Lynch, S., Beresford, N.A., Barnett, C.L.,

554 Beaugelin-Seiller, K. et al., 2010. An international model validation exercise on radionuclide 555 transfer and doses to freshwater biota. J. Radiol. Prot. 30, 299-340.

556 Yankovich, T.L., King-Sharp, K.J., Benz, M.L., Carr, J., Killey, R.W.D., Beresford, N.A., 557 Wood, M.D., 2013a. Do site-specific radiocarbon measurements reflect localized

558 distributions of ${ }^{14} \mathrm{C}$ in biota inhabiting a wetland with point contamination sources. J. Environ.

559 Radioact. 126, 352-366.

560 Yankovich, T.L., King-Sharp, K.J., Benz, M.L., Carr, J., Robertson, E., Killey, R.W.D., 561 Beresford, N.A., Wood, M.D., 2014. Spatial analysis of Carbon-14 dynamics in a wetland 562 ecosystem (Duke Swamp, Chalk River Laboratories, Canada). J. Environ. Radioact. 137, 173563180.

564 Yankovich, T., Beresford, N.A., Fesenko S., Fesenko, J., Phaneuf, M., Dagher, E., Outola, I., 565 Andersson, P., Thiessen, K., Ryan, J., Wood, M.D., Bollhöfer, A., Barnett, C.L., Copplestone, 566 D., 2013b. Establishing a database of radionuclide transfer parameters for freshwater wildlife. 567 J. Environ. Radioact. 126, 299-313. 570 assessment for the proposed IRUS low level waste disposal facility at AECL's Chalk River 571 Laboratories. Atomic Energy of Canada Limited Technical Record, AECL-TR-791. 
2 Table 1

3 Model names, and origin of model parameters used in this wetland scenario exercise.

\begin{tabular}{|c|c|c|c|c|}
\hline $\begin{array}{l}\text { Name of } \\
\text { approach in this } \\
\text { chapter }\end{array}$ & Model & $\begin{array}{l}\text { Origin of } \\
\text { transfer } \\
\text { parameters }\end{array}$ & $\begin{array}{l}\text { Origin of organism } \\
\text { dimensions }\end{array}$ & C-14 approach \\
\hline $\begin{array}{l}\text { ERICA } \\
\text { (eriss/ARPANSA) }\end{array}$ & ERICA Tool & Model default ${ }^{1}$ & Model default & Specific activity approach \\
\hline ERICA (ANSTO) & ERICA Tool & Model default & $\begin{array}{l}\text { Mainly model default } \\
\text { but also two new } \\
\text { organism sizes from } \\
\text { expert judgement or } \\
\text { own data }\end{array}$ & ERICA default $\mathrm{CR}_{\text {wo-air }}$ \\
\hline ERICA (CEH) & ERICA Tool & $\begin{array}{l}\text { Mainly draft } \\
\text { TRS but also } \\
\text { ICRP derived } \\
\text { CR for duck }\end{array}$ & Model default & Specific activity approach \\
\hline $\begin{array}{l}\text { ERICA } \\
(\text { SCK・CEN) }\end{array}$ & ERICA Tool & Draft TRS & $\begin{array}{l}\text { Mainly model default, } \\
\text { but also some new } \\
\text { organism sizes from } \\
\text { expert judgement or } \\
\text { own data }\end{array}$ & Specific activity approach \\
\hline RESRAD & RESRAD-Biota & Draft TRS & $\begin{array}{l}\text { Chosen from a set of } \\
\text { model default } \\
\text { organism sizes. }\end{array}$ & Specific activity approach \\
\hline K-BIOTA & K-Biota & Draft TRS & $\begin{array}{l}\text { Mainly from expert } \\
\text { judgement but also } \\
\text { ARKiv and ICRP } 108\end{array}$ & Specific activity approach \\
\hline
\end{tabular}

6 
Table 2

Input data given for a wetland assessment exercise. Mean values (minimum and maximum values within brackets) of environmental media activity concentrations measured in three

20 wetlands; Steel Creek, Utnora, and Duke Swamp.

\begin{tabular}{|c|c|c|c|c|}
\hline & $\begin{array}{c}{ }^{137} \mathrm{Cs} \\
(\mathrm{Bq} / \mathrm{kg} \text { d.w. or } \mathrm{Bq} / \mathrm{l})\end{array}$ & $\begin{array}{l}{ }^{14} \mathrm{C} \\
(\mathrm{Bq} / \mathrm{kg})\end{array}$ & $\begin{array}{c}{ }^{14} \mathrm{C} \\
(\mathrm{Bq} / \mathrm{g} \mathrm{C})\end{array}$ & References \\
\hline $\begin{array}{c}\text { Steel Creek } \\
\quad \text { soil } \\
\text { water }\end{array}$ & $\begin{array}{l}3500(210-19000) \\
0.81\end{array}$ & $\begin{array}{l}- \\
-\end{array}$ & $\begin{array}{l}- \\
-\end{array}$ & $\begin{array}{l}\text { Brisbin et al., 1974a } \\
\text { RAC, } 2001 \text { - appendix K }\end{array}$ \\
\hline $\begin{array}{l}\text { Utnora } \\
\text { soil } \\
\text { water }\end{array}$ & $\begin{array}{l}30000(12000-74000) \\
0.2\end{array}$ & $\begin{array}{l}- \\
-\end{array}$ & $\begin{array}{l}- \\
-\end{array}$ & $\begin{array}{l}\text { Stark et al., 2006; Stark, } \\
\text { unpublished data }\end{array}$ \\
\hline $\begin{array}{l}\text { soil } \\
\text { air }\end{array}$ & - & $7600(310-27000)$ & $14(0.56-50)$ & $\begin{array}{l}\text { Yankovich et al } 2014 \\
\text {; Yankovich et al 2013a; } \\
\text { Yankovich et al 2008a and } \\
2008 b\end{array}$ \\
\hline
\end{tabular}


Table 3

37 Summary of organisms included in the scenario (Anderson et al., 1973; Brisbin et al., 1974b; Dapson and Kaplan, 1975; RAC, 2001- Chapter 11; Stark et al., 2004; Stark unpublished data;

39 Yankovich et al., 2013a)

\begin{tabular}{|c|c|c|}
\hline Wetland & Vegetation & Animal \\
\hline $\begin{array}{l}\text { Steel Creek } \\
\text { Swamp }\end{array}$ & $\begin{array}{l}\text { Grasses (Scirpus sp., Juncus } \\
\text { sp.), Sedges (Andropogon sp.), } \\
\text { Alder tree (Alnus serrulata) } \\
\text { Shrubs (Myrica cerifera), } \\
\text { Willows (Salix nigra). }\end{array}$ & $\begin{array}{l}\text { Green tree frog (Hyla cinerea), } \\
\text { Aquatic snakes, Terrestrial } \\
\text { snakes, Ducks (e.g. Anas } \\
\text { platyrynchos), Spiders (Order } \\
\text { Aranae), Beetles (Order } \\
\text { Coleoptera), Aphids, } \\
\text { Leafhoppers (Order } \\
\text { Homoptera), Cicadas, } \\
\text { Grasshoppers, Crickets (Order } \\
\text { Orthoptera) }\end{array}$ \\
\hline Utnora Swamp & $\begin{array}{l}\text { Spruce (Picea abies), Alder } \\
\text { tree (Alnus glutinosa), Fern } \\
\text { (Matteuccia struthiopteris), } \\
\text { Forbs (Filipendula ulmaria, } \\
\text { Urtica dioica, Scirpus } \\
\text { sylvaticus, Lysimachia } \\
\text { thyrsifolia), Sedges (Carex sp.) }\end{array}$ & Moor frog (Rana arvalis) \\
\hline Duke Swamp & $\begin{array}{l}\text { Peat moss (Sphagnum sp.), } \\
\text { Grass (e.g. Calamagrostis sp.), } \\
\text { Forbs, Ferns (e.g. Thelypteris } \\
\text { palustris), Cedar (Thuja sp.), } \\
\text { Balsam fir (Abies balsamea) }\end{array}$ & $\begin{array}{l}\text { Aerial insects, including deer } \\
\text { flies (Chrysops spp.), horse } \\
\text { flies (Tabanus spp.), other } \\
\text { types of flies (Order Diptera), } \\
\text { wasps (Order Hymenoptera) } \\
\text { and moths (Order Lepidoptera), } \\
\text { Carrion beetles (Family } \\
\text { Silphidae), American bullfrog } \\
\text { (Rana catesbeiana), Green } \\
\text { frogs (Rana clamitans), } \\
\text { Northern leopard frog (Rana } \\
\text { pipens), Mink frog (Rana } \\
\text { septentrionalis), Grey treefrog } \\
\text { (Hyla versicolor), American } \\
\text { toad (Bufo americanus), } \\
\text { Common garter snake } \\
\text { (Thamnophis sirtalis), Deer } \\
\text { mice (Peromyscus } \\
\text { maniculatus), Meadow vole } \\
\text { (Microtus pennsylvanicus), } \\
\text { Northern short-tailed shrew } \\
\text { (Blarina brevicauda), White- } \\
\text { footed mouse (Peromyscus } \\
\text { leucopus) }\end{array}$ \\
\hline
\end{tabular}

40 
46 Concentration ratios for organism in Steel creek and Utnora Swamp as assumed by the 47 different participants. Model applications abbreviated as e: ERICA (eriss/ARPANSA), A: 48 ERICA (ANSTO), C: ERICA (CEH), S: ERICA (SCK•CEN), R: (RESRAD) and K: K-Biota. 


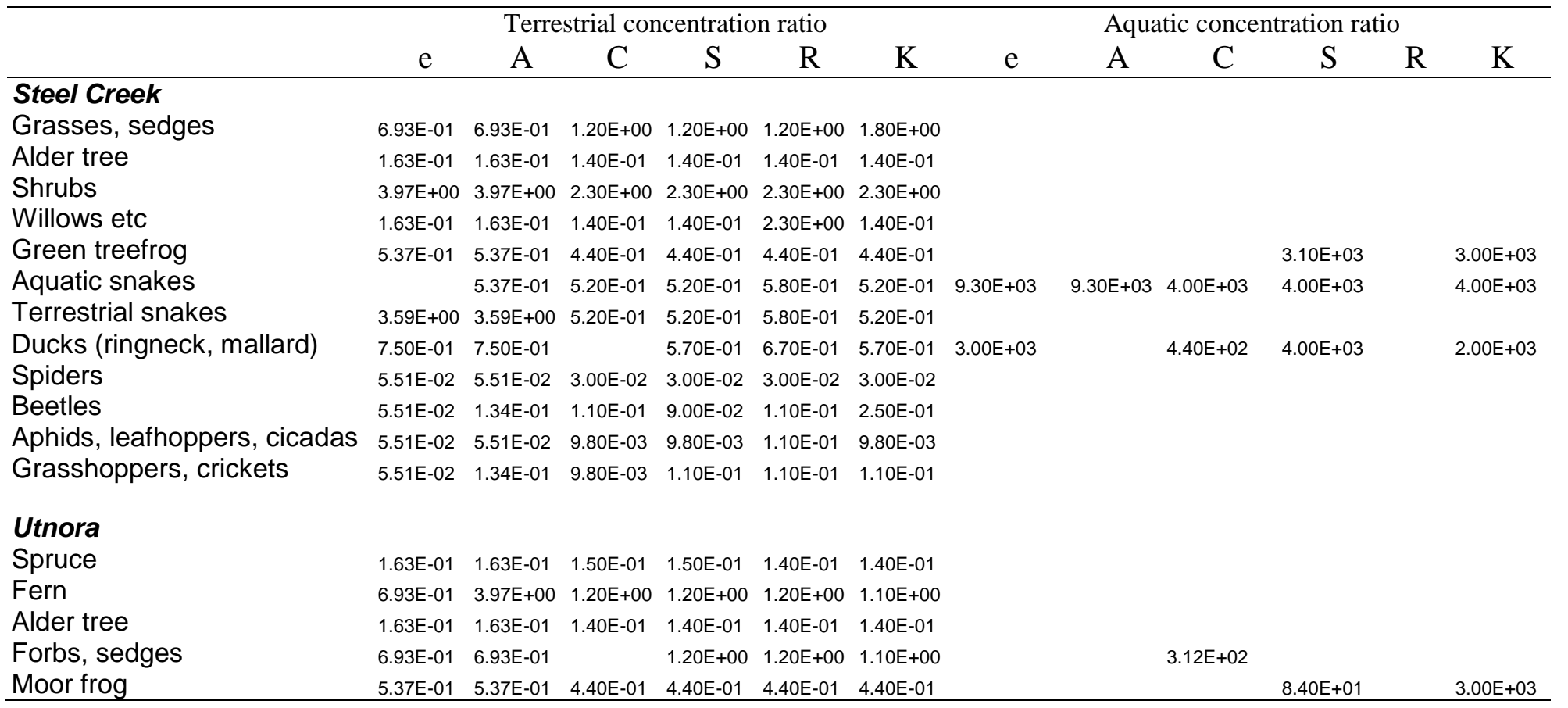




\section{Table 5}

Occupancy factors for organism in Steel creek and Utnora Swamp as assumed by the different participants. Model applications abbreviated as e: ERICA (eriss/ARPANSA), A: ERICA (ANSTO), C: ERICA (CEH), S: ERICA (SCK•CEN), R: (RESRAD) and K: K-Biota.

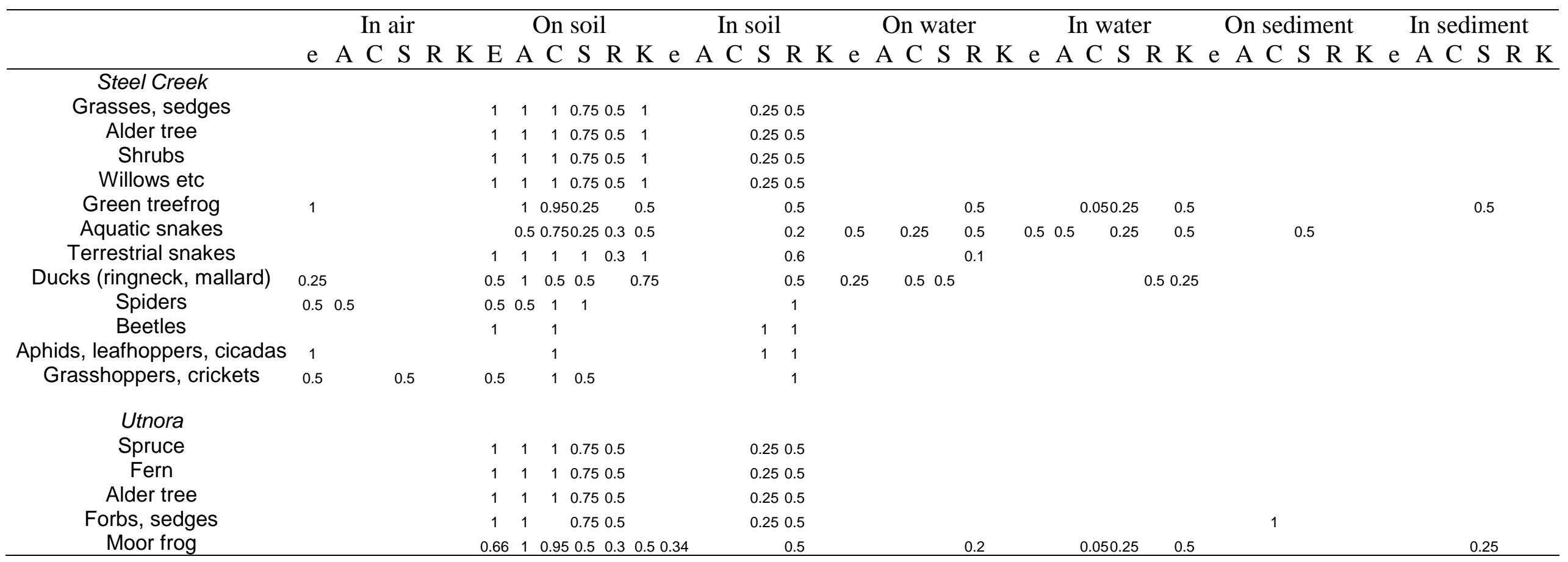




\section{Figures captions}

2 Fig. 1. Location of Steel Creek on the Savannah River Site in South Carolina (Brisbin et

3 al.,1974a); the soil sampling transects are represented by the three lines with letter.

4 Fig. 2. The Utnora Swamp in Sweden. Grey areas indicate wetland areas. Samples included in 5 this scenario are taken in areas indicated by the letters A and B, next to Verkmyra Stream

6 (Stark et al., 2006).

7 Fig. 3. Duke Swamp with sampling points indicated by sample ID (Yankovich et al., 2008a).

8 The sampling points that are included in this exercise are marked with an ellipse.

9 Fig. 4. Mean measured and predicted biota whole organism activity concentrations of ${ }^{137} \mathrm{Cs}$ in 10 Steel Creek Swamp (Anderson et al., 1973; Brisbin et al., 1974b; Dapson and Kaplan, 1975; 11 RAC, 2001-Chapter 11). Organisms included from left to right: treefrog, alder tree, duck, 12 aphids and cicadas, shrub, willow, aquatic/terrestrial snake, spider, beetles, grasshoppers and 13 crickets, and grasses. A range with 3 times above (3:1) and 3 times below (1:3) the mean 14 measured values is indicated.

15 Fig. 5. Mean measured and predicted biota whole organism activity concentrations of ${ }^{137} \mathrm{Cs}$ in Utnora Swamp (Stark et al., 2004; Stark unpublished data). Organisms included from left to right: spruce, alder tree, forbs and sedges, fern, and frog. A range with 3 times above (3:1) and 3 times below (1:3) the mean measured values is indicated.

Fig. 6. Mean measured and predicted whole biota activity concentrations of ${ }^{14} \mathrm{C}$ in Duke Swamp (Yankovich et al., 2013a). Organisms included from left to right: insect, rodent, frog, tree, small plant, and snake. A range with 3 times above (3:1) and 3 times below (1:3) the mean measured values is indicated.

Fig. 7. Estimated internal and external radiation dose rates $(\mu \mathrm{Gy} / \mathrm{h})$ from ${ }^{137} \mathrm{Cs}$ to organisms in Steel Creek Swamp.

Fig. 8. Estimated internal and external radiation dose rates $(\mu \mathrm{Gy} / \mathrm{h})$ from ${ }^{137} \mathrm{Cs}$ to organisms in Utnora Swamp.

Fig. 9. Estimated external and internal radiation dose rates $(\mu \mathrm{Gy} / \mathrm{h})$ from ${ }^{14} \mathrm{C}$ to organisms in Duke Swamp.

Fig. 10. Estimated and measured external radiation dose rates $(\mu \mathrm{Gy} / \mathrm{h})$ from ${ }^{137} \mathrm{Cs}$ to moor frog in Utnora Swamp assuming 100\% occupancy in soil. Measurements were done using frog phantoms (Stark and Pettersson, 2008). Bars are representing the range (min-max) and the points are representing mean values. 


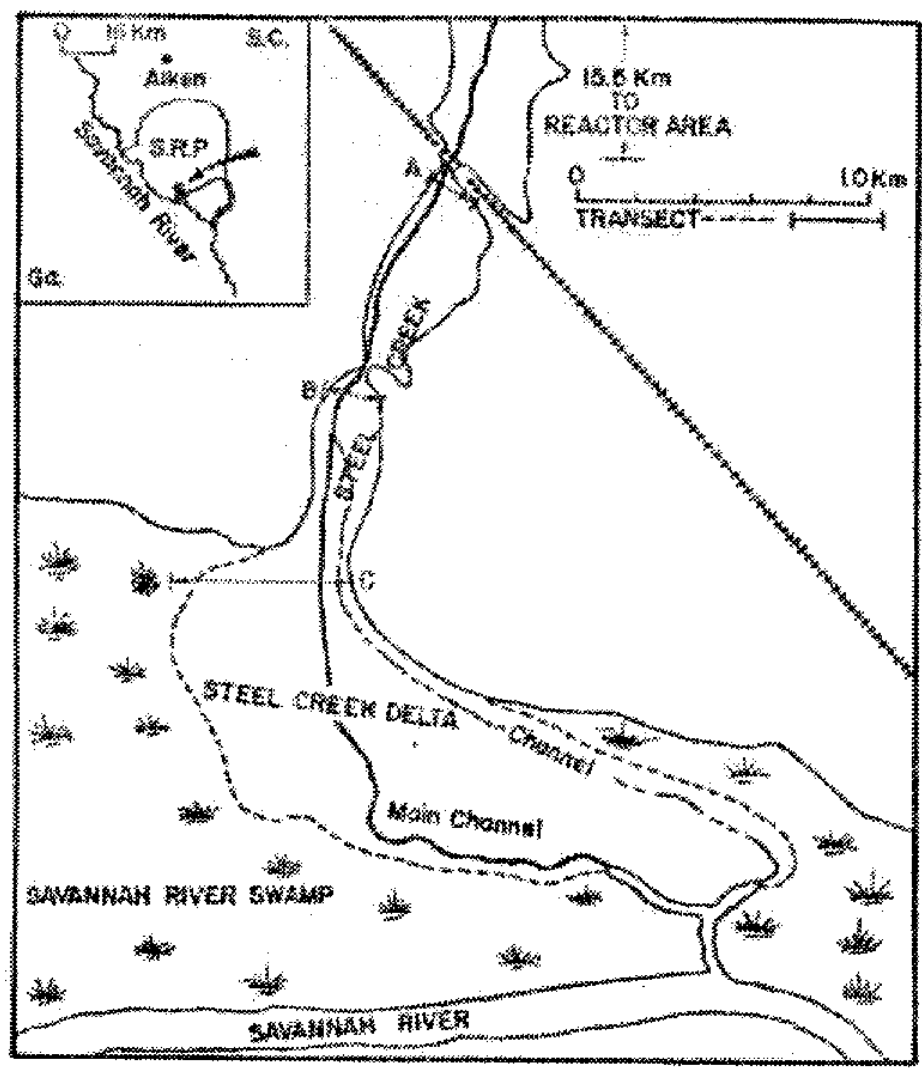

Figure 1. 


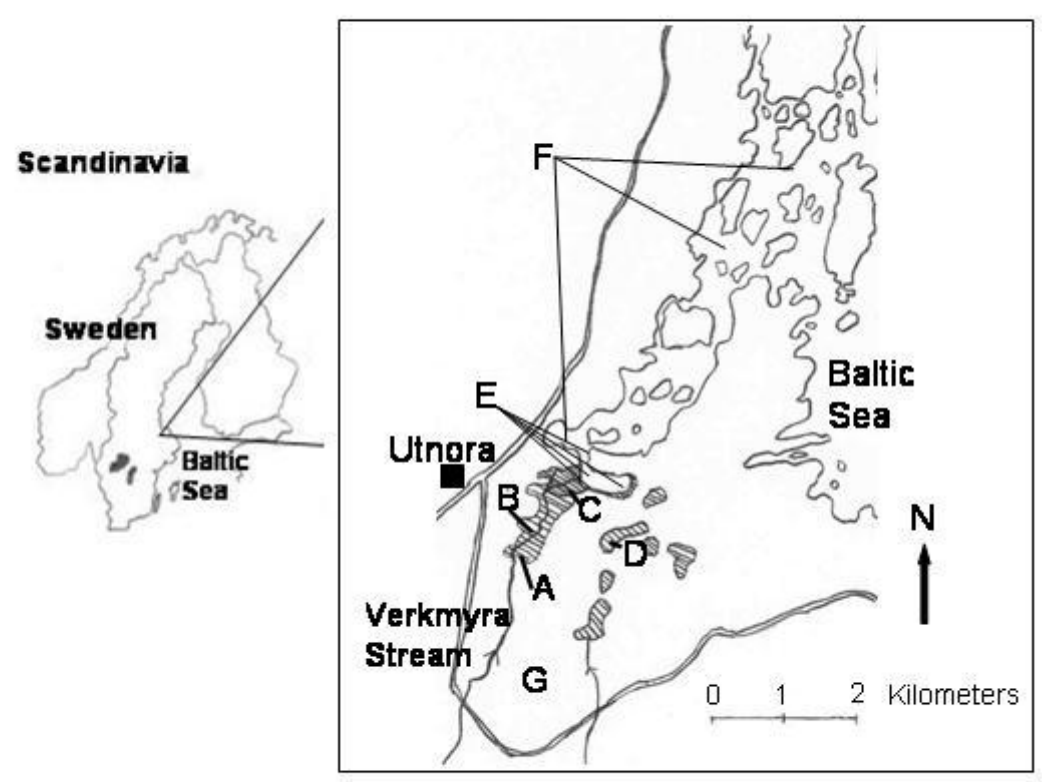

43 Figure 2. 


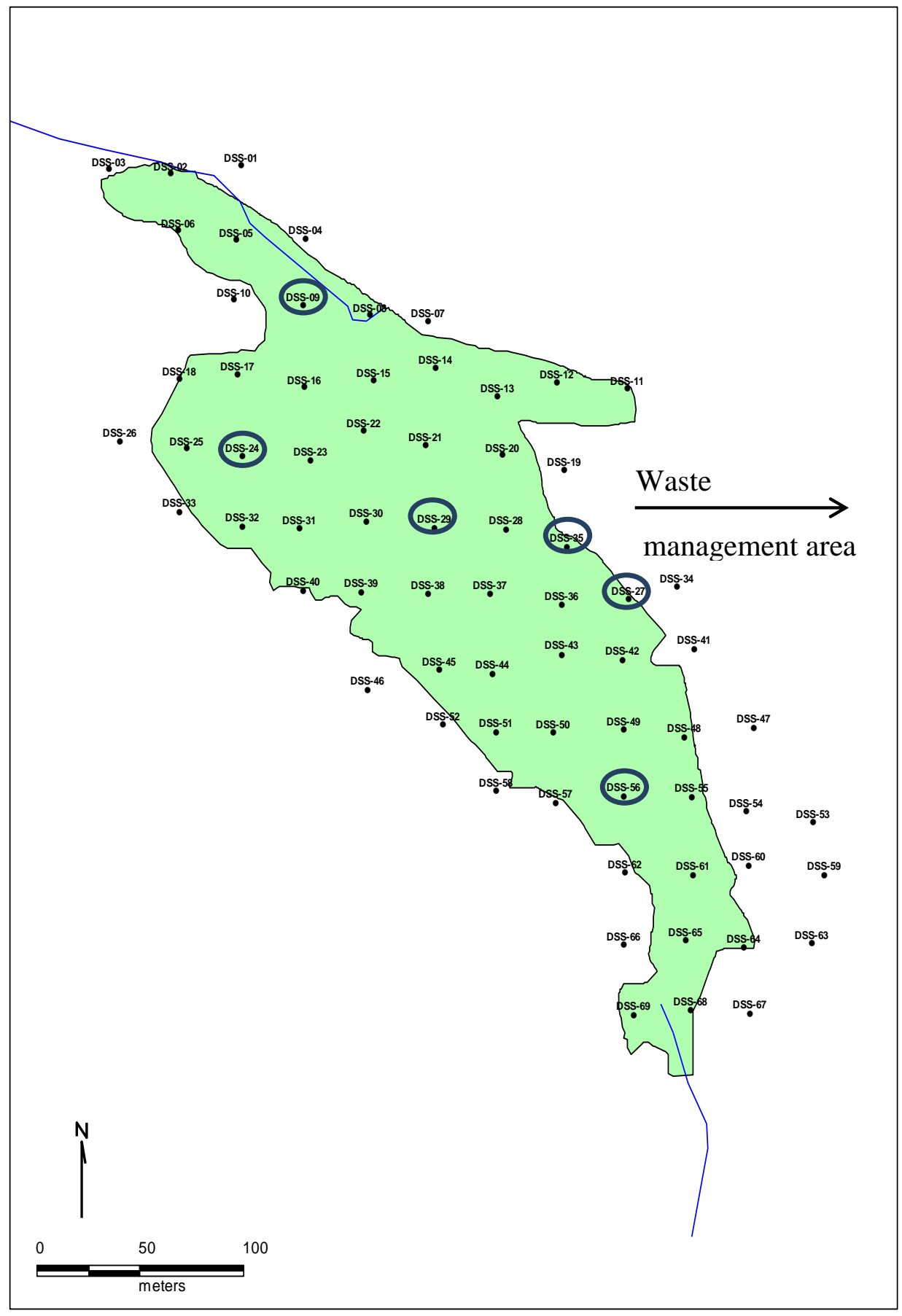
Figure 3. 


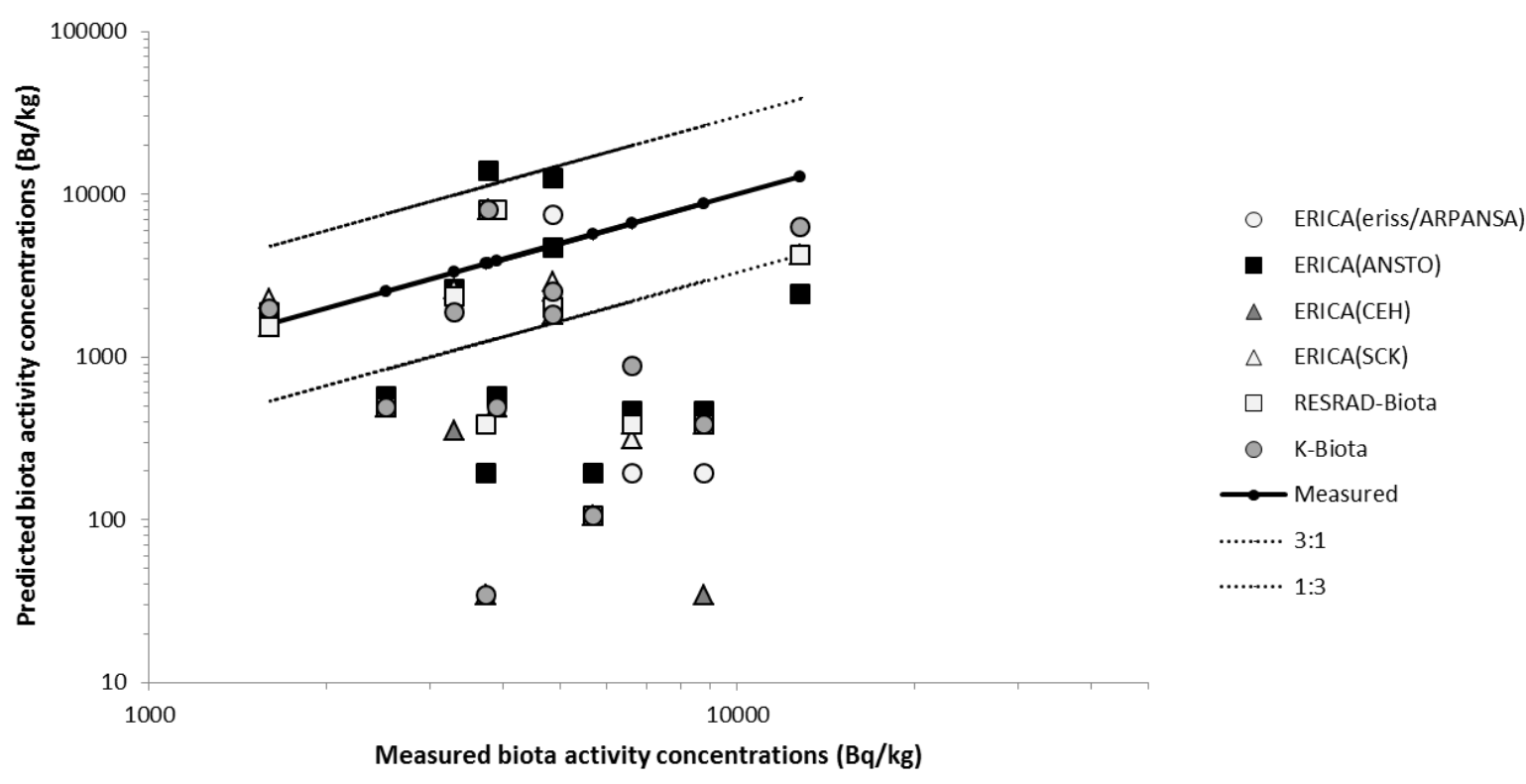

\section{$50 \quad$ Figure 4.}

51

52

53

54 


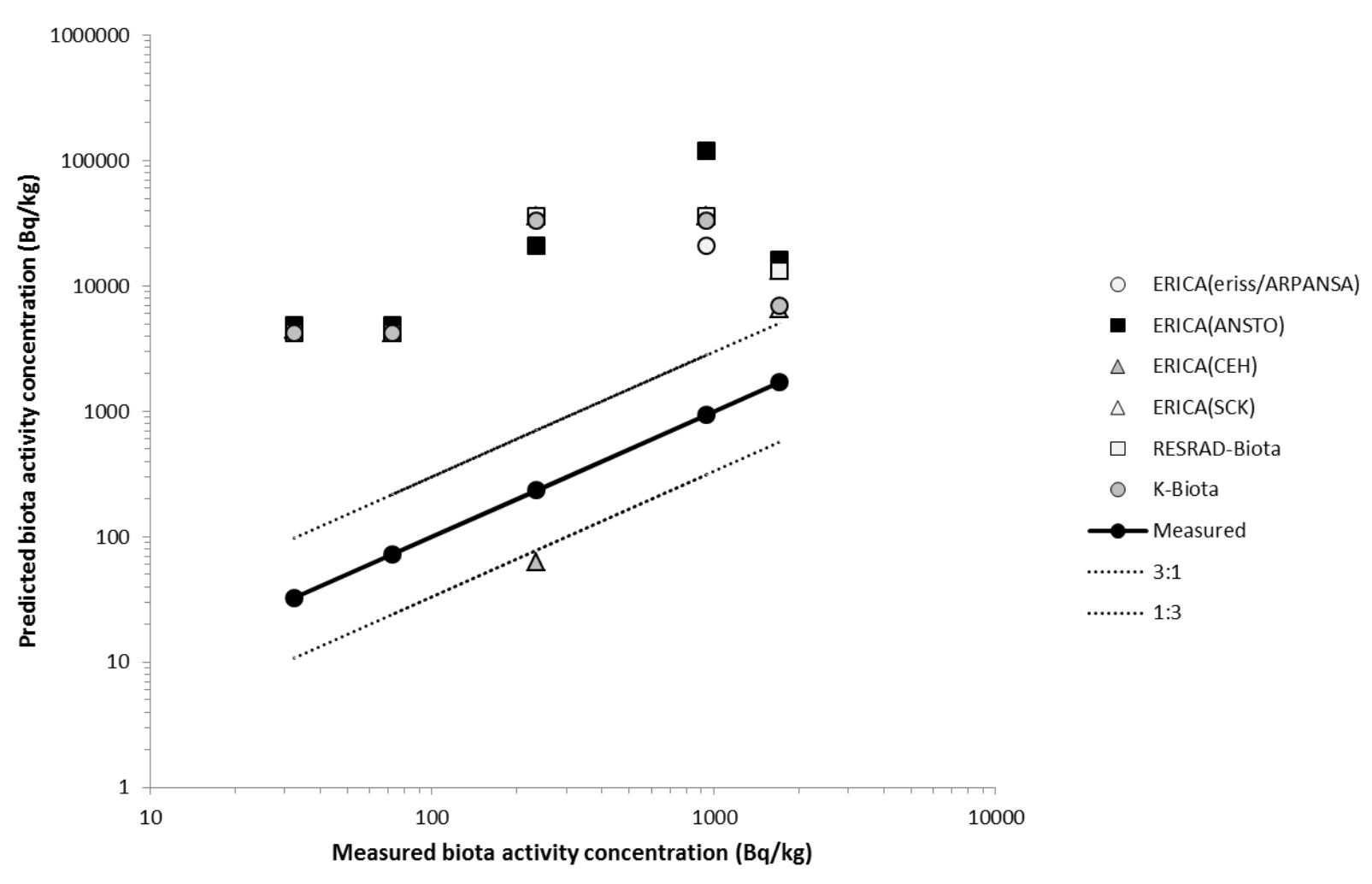

$70 \quad$ Figure 5.

71

72

73

74

75

76 


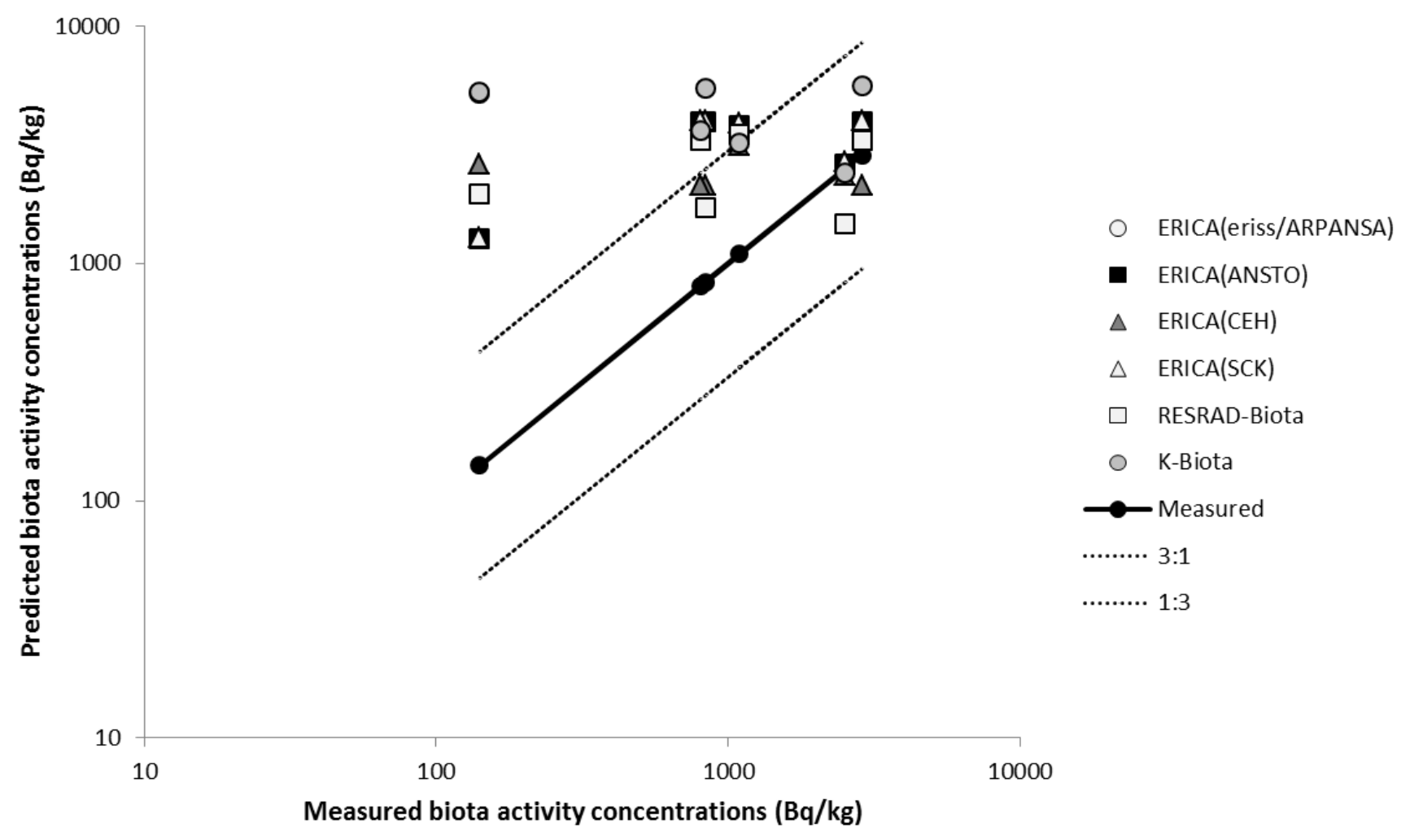

$79 \quad$ Figure 6.

80

81

82

83

84

85

86

87 


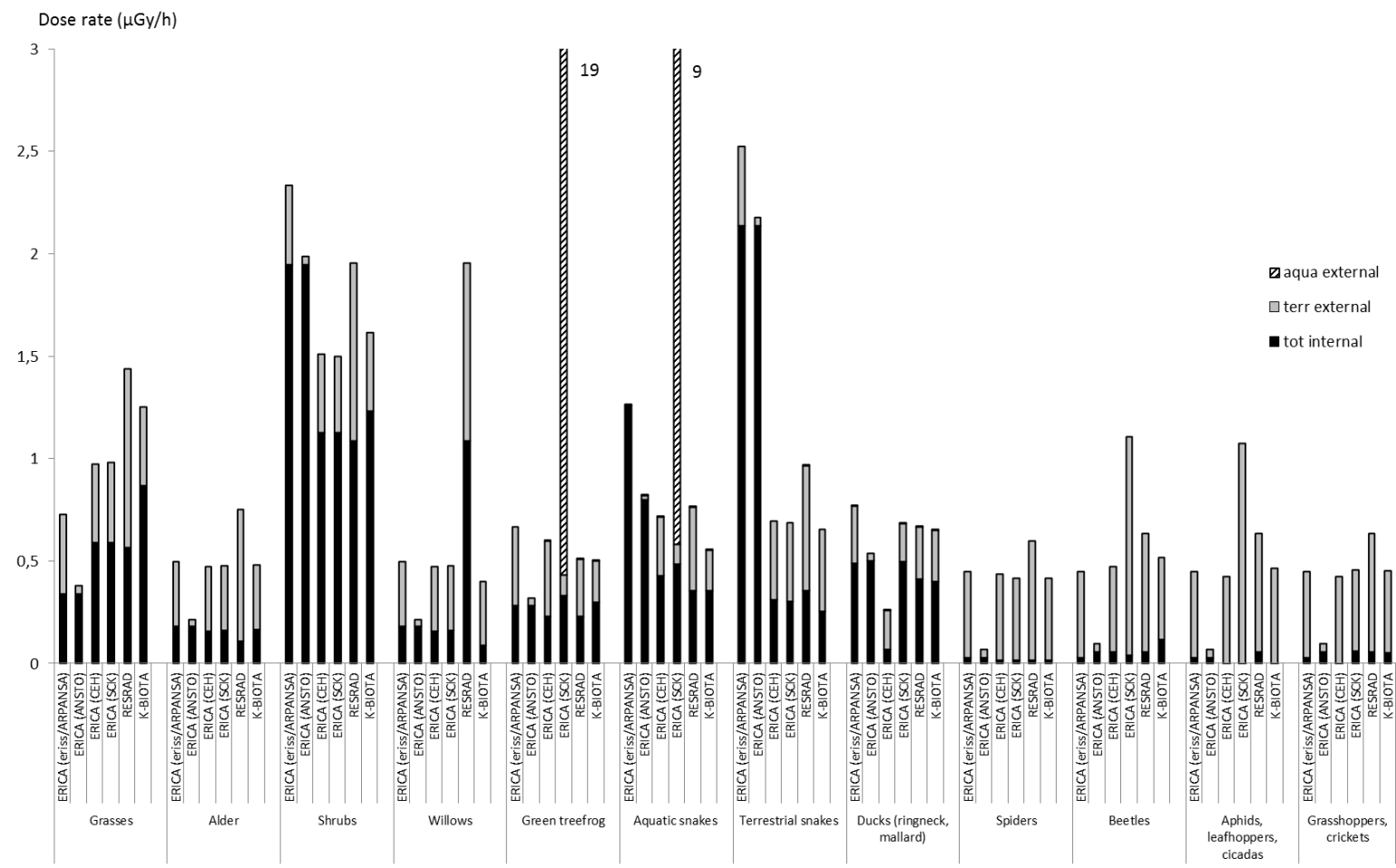

88

Figure 7.

90

91

92

93 


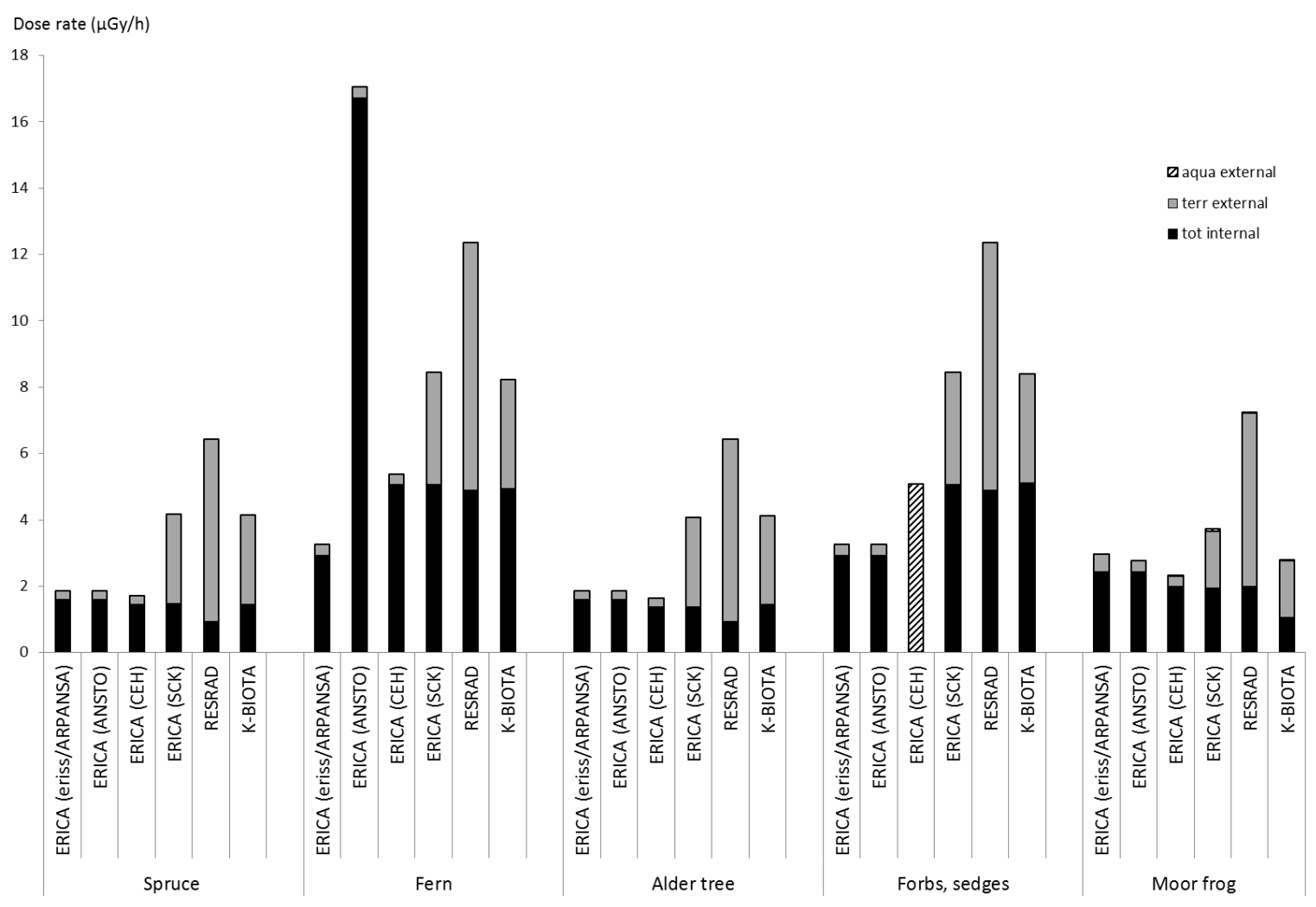

Figure 8. 


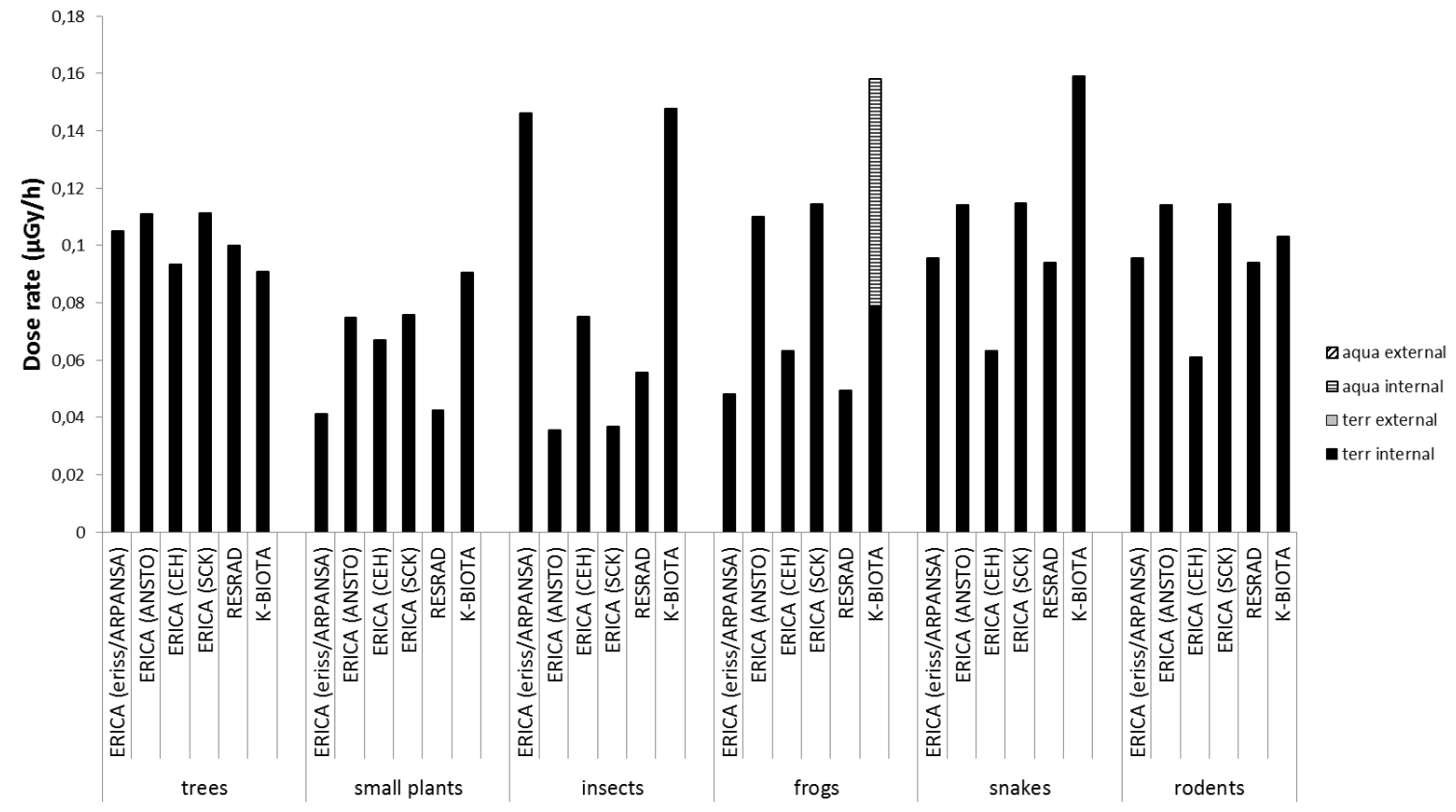

109

$110 \quad$ Figure 9.

111

112

113 


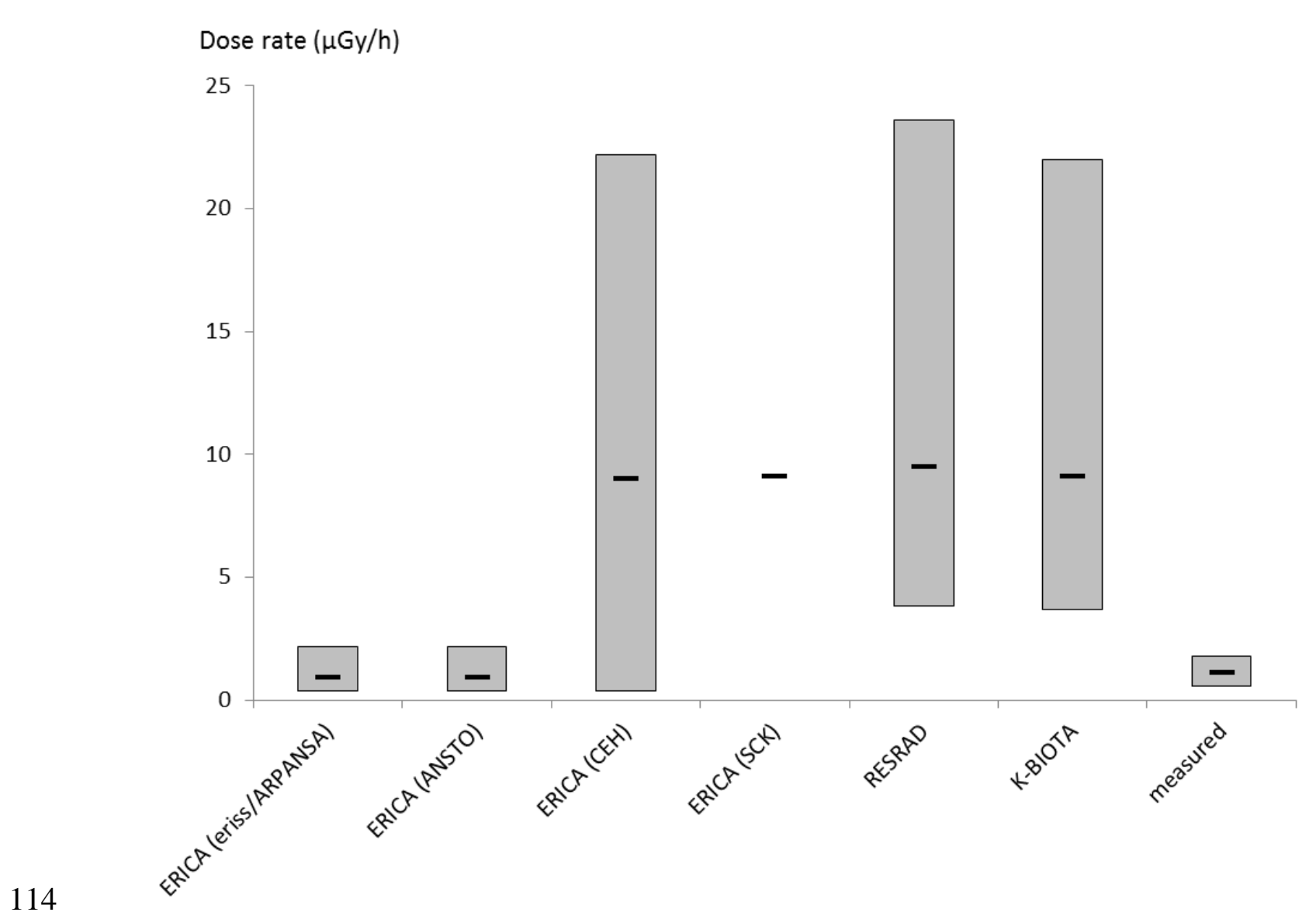

$115 \quad$ Figure 10.

116

117

118

119

120

121

122

123

124

125

126 